\title{
Role of a Heat Shock Transcription Factor and the Major Heat Shock Protein Hsp70 in Memory Formation and Neuroprotection
}

\author{
Olga G. Zatsepina ${ }^{\dagger}$, Michael B. Evgen'ev ${ }^{\dagger}$ and David G. Garbuz *
}

\section{check for}

updates

Citation: Zatsepina, O.G.; Evgen'ev, M.B.; Garbuz, D.G. Role of a Heat

Shock Transcription Factor and the Major Heat Shock Protein Hsp70 in Memory Formation and

Neuroprotection. Cells 2021, 10, 1638. https://doi.org/10.3390/cells10071638

Academic Editor: Alexander

E. Kabakov

Received: 27 May 2021

Accepted: 25 June 2021

Published: 29 June 2021

Publisher's Note: MDPI stays neutral with regard to jurisdictional claims in published maps and institutional affiliations.

Copyright: (c) 2021 by the authors. Licensee MDPI, Basel, Switzerland. This article is an open access article distributed under the terms and conditions of the Creative Commons Attribution (CC BY) license (https:// creativecommons.org/licenses/by/ $4.0 /)$.
Laboratory of Molecular Mechanisms of Biological Adaptation, Engelhardt Institute of Molecular Biology of the Russian Academy of Sciences, 119991 Moscow, Russia; olzacepina@yandex.ru (O.G.Z.); misha672011@yahoo.com (M.B.E.)

* Correspondence: dgarbuz@yandex.ru

t These two authors contributed equally to the work.

Abstract: Heat shock proteins (Hsps) represent the most evolutionarily ancient, conserved, and universal system for protecting cells and the whole body from various types of stress. Among Hsps, the group of proteins with a molecular weight of $70 \mathrm{kDa}(\mathrm{Hsp} 70)$ plays a particularly important role. These proteins are molecular chaperones that restore the native conformation of partially denatured proteins after exposure to proteotoxic forms of stress and are critical for the folding and intracellular trafficking of de novo synthesized proteins under normal conditions. Hsp70s are expressed at high levels in the central nervous system (CNS) of various animals and protect neurons from various types of stress, including heat shock, hypoxia, and toxins. Numerous molecular and behavioral studies have indicated that Hsp70s expressed in the CNS are important for memory formation. These proteins contribute to the folding and transport of synaptic proteins, modulate signaling cascades associated with synaptic activation, and participate in mechanisms of neurotransmitter release. In addition, HSF1, a transcription factor that is activated under stress conditions and mediates Hsps transcription, is also involved in the transcription of genes encoding many synaptic proteins, whose levels are increased in neurons under stress and during memory formation. Thus, stress activates the molecular mechanisms of memory formation, thereby allowing animals to better remember and later avoid potentially dangerous stimuli. Finally, Hsp70 has significant protective potential in neurodegenerative diseases. Increasing the level of endogenous Hsp70 synthesis or injecting exogenous Hsp70 reduces neurodegeneration, stimulates neurogenesis, and restores memory in animal models of ischemia and Alzheimer's disease. These findings allow us to consider recombinant Hsp70 and/or Hsp70 pharmacological inducers as potential drugs for use in the treatment of ischemic injury and neurodegenerative disorders.

Keywords: molecular chaperones; Hsp70; heat shock factor 1 (HSF1); stress; memory formation; long-term potentiation; ischemic injury; neurodegenerative disorders

\section{Introduction}

The ability of organisms to survive in constantly changing environmental conditions, to reproduce, and to occupy new ecological niches largely depends on the functioning of the nervous system, which is critical for the input of new information, its processing, and motor response necessary for rapid avoidance of danger. Rapid behavioral responses may help to reduce or completely prevent environmental stressors, such as temperature increases, dehydration, changes in the chemical composition of aquatic organisms, and predator attacks [1]. Successful reactions to avoid dangerous influences are based on memory [2-4]. The ability to remember and form conditioned reflexes to avoid danger has been shown for a wide variety of organisms, such as nematodes, molluscs, crustaceans, Drosophila, and mammals [4-10]. Notably, the formation of memory occurs in parallel with 
the activation of the metabolic systems in the response to stress, i.e., an adaptive response that protects individual cells and the whole organism from various stress factors. The adaptive response to stress also protects the synaptic network (the memory substrate) from the damaging effects of different stress factors and during neurodegeneration processes in aging or proteinopathies [11].

The most universal system of protection from any stressful influence is represented by a group of genes encoding so-called "heat shock proteins" (Hsps) or stress proteins. These proteins provide a certain degree of cell resistance to hyperthermia, hypoxia, oxidative stress, toxins of various types, radiation, etc. [12]. A group of proteins with a molecular weight of $70 \mathrm{kDa}$ (HSP70) plays a special role in ensuring the survival of the cell in stressful conditions and maintaining normal metabolism. Hsp70 plays an important role in protecting nerve cells during ischemia and neurodegenerative diseases. The experimental data available at the moment allow us to postulate the crucial role of Hsp70 in memory formation, nervous system development, and maintaining the functioning of the nervous system during aging.

\section{Materials and Methods}

A comprehensive literature review was conducted to identify and critically evaluate studies analyzing the possible relationships between Hsp70 and memory or neuroprotection. The PubMed, PubMed Central, and Scopus databases were searched for related research articles. Selection and data collection of study were carried our form blind and independently by all three coauthors. Keywords for searching included the following: Hsp70, heat shock factor 1 (HSF1), stress, memory, short-term potentiation, long-term potentiation, short-term memory, long-term memory, ischemic injury, neuroprotection, neurodegenerative disorders, and development of nervous system. Discrimination by year of publication was not used. Only articles already published or accepted for publication were used for citation in the review.

In addition to the standard search in the PubMed and Scopus databases, article search was based on work with Entrez-direct utility ( ftp:/ / ftp.ncbi.nih.gov/entrez/entrezdirect/ accessed on 12-13 April 2021), which provides an API-like access to NCBI PubMed database. Entrez-direct is able to fetch all articles whose titles matching a regular expression. The data obtained is in MEDLINE format, containing all the basic metadata of article containing abstract text and year of publication. Subsequent analysis of article metadata included keyword extraction with Rapid Automatic Keyword extraction algorithm (RAKE), implemented in Udpipe R package (https:/ / ufal.mff.cuni.cz/udpipe accessed on 15 April 2021), calculating keyword co-occurrence rates, and time-dependent trend analysis of normalized keywords and MEDLINE terms frequencies. The data acquired allowed us to work with most relevant scientific articles in this paper.

\section{Mechanisms of Hsp70 Regulation and Memory Formation}

The mechanism of action of Hsps is based on their ability to interact with the hydrophobic regions of partially denatured proteins, thereby preventing their aggregation and promoting the recovery of their native conformation. Hsp70 also mediates the correct folding and transport of newly synthesized proteins under normal conditions (Figure 1) [11]. Proteins with similar activities are called molecular chaperones. The most versatile molecular chaperones are proteins belonging to the Hsp70 family (each member with a molecular weight of approximately $70 \mathrm{kDa}$ ). Hsp70 is one of the most conserved cellular proteins and is found in the cells of all studied organisms at all stages of phylogeny [13,14]. The Hsp70 family, as well as other families of molecular chaperones, includes a group of proteins whose synthesis is induced by stress (inducible Hsp70) and several proteins that are synthesized mainly under normal physiological conditions (constitutive Hsc70) [15]. Hsc70 primarily facilitates the folding and intracellular transport of proteins, while Hsp70 is primarily involved in refolding or degradation of proteins that have been partially damaged or denatured under stress conditions (Figure 1). Notably, Hsp70 is a strong inhibitor of apoptosis [16]. 
Intracellular

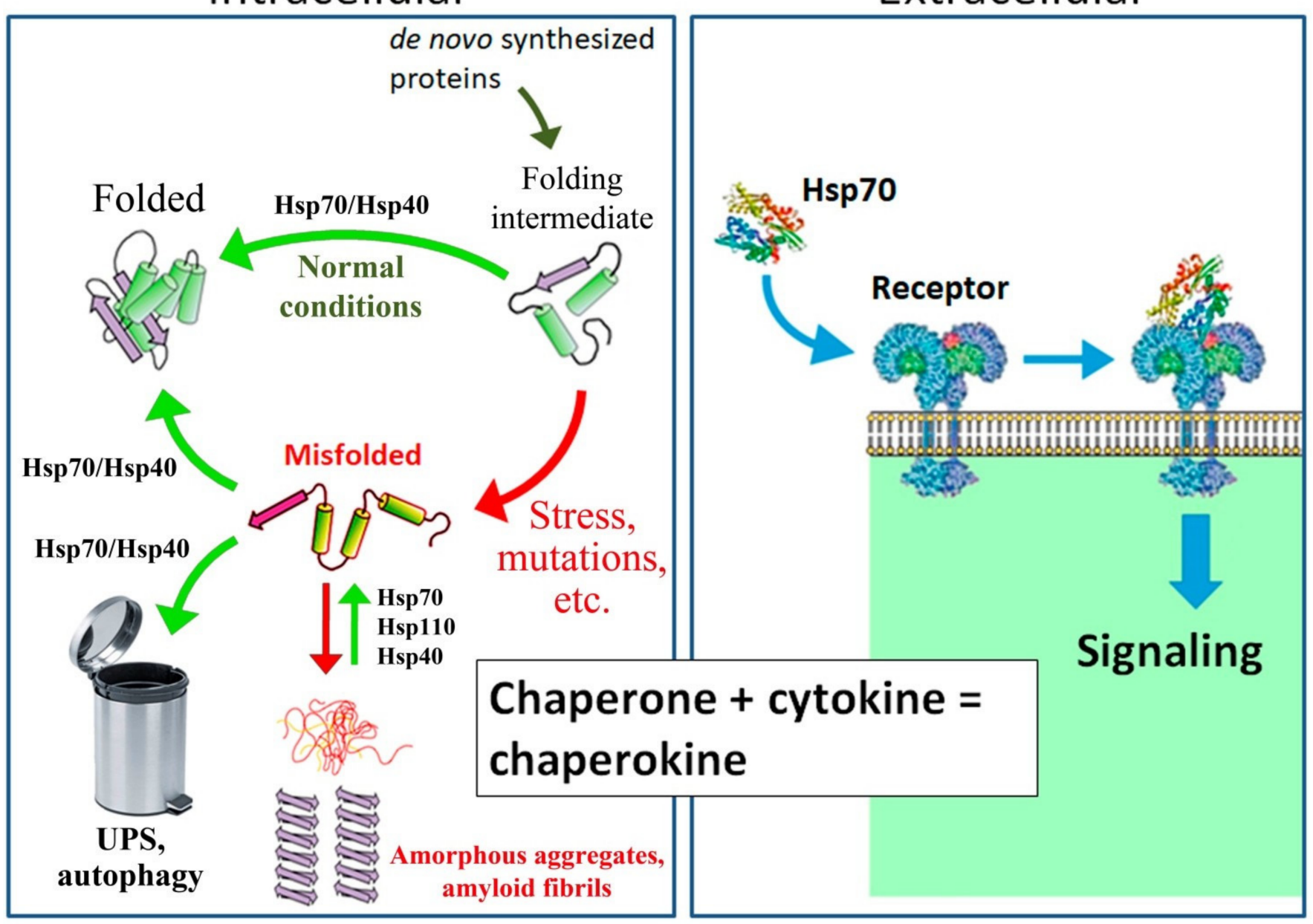

Figure 1. Mechanism of action of intracellular and secreted proteins of the Hsp70 family. As an intracellular housekeeping protein, Hsp70, in cooperation with Hsp40 and other co-chaperones, folds and sorts newly synthesized proteins in cells under normal conditions. Under proteotoxic stress and in the case of certain mutations, misfolded proteins accumulate in the cytosol. Hsp70, in cooperation with co-chaperone Hsp40, restores the native conformation of partially denatured proteins and directs irreversibly damaged proteins to the ubiquitin-proteasome system (UPS) or lysosomes by autophagy. In addition, Hsp70 in combination with Hsp110 and Hsp40 promotes the dissolution of protein aggregates, such as $\alpha$ synuclein [12,17-20]. As a secreted protein, Hsp70 is recognized by TLR2/4 and CD91 receptors and participates in the regulation of innate immunity, similar to classical cytokines; hence, Hsp70 is often called a "chaperokin" [21-28].

The induction of heat shock protein synthesis is triggered under stress that causes abnormal protein conformation [29]. The transcriptional induction of Hsp genes is mediated by a family of transcription factors called "HSFs" (heat shock factors) [30,31]. When the concentrations of partially denatured proteins, cAMP, and calcium ions increase in the cytosol (due to heat shock or other types of stress), the transcription factor HSF1 is trimerized and phosphorylated. Activated HSF1 binds to heat shock elements (HSEs) located in Hsp promoters, resulting in a ten- to hundred-fold increase in transcription intensity [30-33]. In mammals, constitutive Hscs are expressed with the participation of another transcription factor, HSF2, which is active under normal conditions [34].

Some Hsps, in particular Hsp70, in addition to serving as molecular chaperones in intracellular processes, are secreted into the intercellular space, where they play a role in intercellular communication. Secreted Hsps are recognized by a number of patternrecognizing receptors (TLR2, TLR4, and others) (Figure 1). Therefore, extracellular Hsp70 was initially characterized as one of the damage-associated molecular patterns (DAMPs), intracellular molecules that are released from damaged or dying cells due to trauma or in- 
fection and activate the innate immune response via pattern-recognizing receptors located mostly on neutrophils and macrophages [35]. Subsequently, it has been suggested that the pro-inflammatory effects of exogenous Hsp70 are explained by its contamination with lipopolysaccharide (LPS), which is capable of inducing the reaction of macrophages and neutrophils, even when LPS is present in trace amounts [36]. However, the results obtained using Hsp70 isolated from eukaryotic expression systems (for example, the baculovirus system) and free from contamination by LPS and bacterial proteins indicated that exogenous Hsp70 may have an anti-inflammatory effect. This effect involves suppression of the secretion of pro-inflammatory cytokines, reactive oxygen species and NO by neutrophils and macrophages and reduction in the nuclear transport of NF-kB [21-27].

The formation of memory at the molecular level occurs in several stages. First, shortterm memory (STP) is formed, which does not require the synthesis of new proteins. It is believed that the formation of short-term memory involves the activation of adenylate cyclase and the production of cAMP, which leads to the activation of protein kinase A (PKA). Activated PKA phosphorylates a wide range of proteins, including potassium and calcium channel subunits, leading to the strengthening of pre-existing synaptic connections [37].

Long-term memory requires, in addition to posttranslational modifications and activation of existing synapses, the synthesis of new proteins and the formation of new synapses [37,38]. The formation of long-term memory and its consolidation requires the repetition of learning stimuli, which leads to a prolonged increase in the level of cAMP and phosphorylation of the transcription factor CAMP response element (CRE)-binding protein (CREB), as well as the induction of several genes with CRE motifs (CREB targets) in the promoter region $[39,40]$. The CREB-mediated response to extracellular stimuli is modulated by a set of protein kinases (PKA, CaMKII, CaMKIV, RSK2, ERK1/2, and PKC) and phosphatases (PP1 and calcineurin) [37,41]. At the next stage, both the de novo transcribed mRNAs and the resting mRNAs stored locally at the synapses are translated, further stabilizing the synapse.

Strengthening of both pre-existing and newly formed synaptic connections induced by brief high-frequency stimulation is referred to as long-term potentiation (LTP) [42]. LTP formation is associated with enhanced neurotransmitter release and is one of the main mechanisms underlying learning and memory [42,43]. In most synapses that support LTP, there is a postsynaptic increase in the concentration of calcium, mediated by the activation of NMDA (N-methyl-D-aspartate) receptors. An increase in calcium levels leads to the activation of CaMKII, which is expressed both in presynaptic and postsynaptic terminals. On the presynaptic side, the protein substrates for CaMKII phosphorylation include synapsin, synaptotagmin, and synaptophysin, which play key roles in the release of neurotransmitters. On the postsynaptic side, CaMKII substrates include several other proteins, such as $\alpha$-actinin, PSD95, the synaptic adhesion protein densin-180, microtubuleassociated protein 2 (MAP2) and neurofilament $L$. Phosphorylation of these proteins leads to cytoskeletal rearrangement and structural changes in synapses, further strengthening the connection [43]. The memorization sequence is given in Figure 2.

Stimuli that require memorization are often associated with various types of stress. Animals need to remember potentially dangerous environmental impacts (temperature changes, predator attacks, etc.) that require an adequate response (avoidance or defense), as well as needing to be aware of their own actions, remembering those that may lead to negative consequences. Most likely, through these connections during the course of evolution, the relationship between the stress response systems, in particular the mechanisms of Hsp70 induction, and memory was formed and consolidated. It has been shown that the stressful effects of moderate-intensity stressors contribute to the formation of LTP and memory [6]. It has also been demonstrated that Hsp70 family members, which are universal molecular chaperones, are involved in the processes of protein synthesis and trafficking that are necessary for the maintenance of existing synapses and the formation of new synapses. Finally, Hsp70 may act as a neuroprotector, to some extent, reducing the impact of damaging factors and ageing of the nervous system, including memory 
deterioration. Therefore, it is evident that the relationship between Hsp70 functions and memory formation is of fundamental interest and carries promise for the treatment of age-related neurodegenerative diseases, such as Alzheimer's disease.

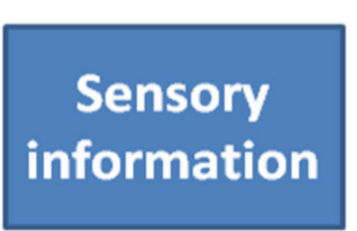

Learning

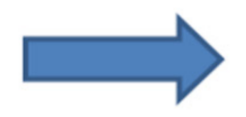

cAMP increase,

posttranslational

modifications of

synaptic proteins,

activation of

existing synapses

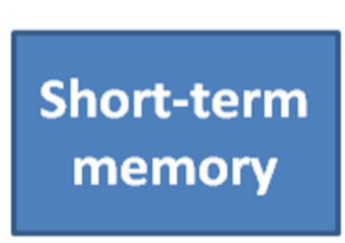

Consolidation
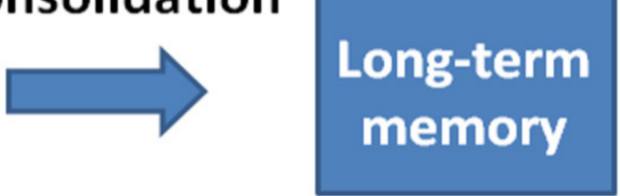

\section{Sustained cAMP}

increase, activation of

CREB and HSF, synaptic

protein expression,

formation of a new

synapses

Figure 2. Summary of the sequence of events during memory formation [37,38,41,42].

\section{Relationship between the Stress Response System and Memory}

Environmental and physiological stresses activate the transcription of hsps in all studied organisms mainly through activation of HSF family members [44]. In addition to HSEs (heat shock elements), which are targets of HSF1, the promoter region of mammalian hsp70 genes contains sterol response element (SRE) motifs that mediate the induction of Hsp70 by growth factors (e.g., nerve growth factor, NGF) and a CRE motif, which is necessary for the binding of the phosphorylated form of CREB $[45,46]$. The presence of CRE motifs in the promoter region of $h s p 70$ genes suggests its possible role in the processes of neuroregulation and memory. Phosphorylated CREB is known to initiate the transcription of several genes associated with memory consolidation processes $[37,47,48]$. Both CREB and HSF1 are activated under stress conditions and involve the participation of several stressinduced signaling cascades (MAPK, PKA, PKC, CaMKII, and Akt) in response to an increase in $\mathrm{Ca}^{2+}$, cAMP, and other low-molecular-weight mediator concentrations [31,49-54]. It has been demonstrated that increased $\mathrm{Ca}^{2+}$ levels and activation of CaMKII and PKC are involved in both the regulation of Hsp70 transcription and memory formation $[55,56]$.

Binding sites of the transcription factor FOXO/DAF-16 have been found in the promoter region of Drosophila melanogaster hsp70 genes [57]. It has also been shown that FOXO/DAF-16 plays an important role in learning and memory, as well as in stress resistance in Caenorhabditis elegans [58,59]. Furthermore, induction of Hsp70 has been shown to be expressed when tasks related to learning and memory are undertaken (see below) [60-62].

To date, a large number of studies have indicated an important role of HSF1 in the processes of memory formation. For instance, it has been demonstrated that HSF1 activation leads to improved cognitive abilities $[63,64]$ and that loss of HSF1 activity is associated with neurodegeneration [65]. Notably, the promoters of genes encoding many synaptic proteins, in particular, PSD95, synapsin I, and synaptophysin, contain canonical HSE sequences. Activation of HSF1 with 17-aminoallylgeldanamycin (17-AAG) has been shown to increase the expression of PSD95, synapsin I, synaptophysin, SAP97, and the neurotrophic factor BDNF, a key regulator of synaptic plasticity [66,67]. In addition, 17-AAG has been shown to increase the expression of Hsp70 and Hsp27 in neurons in vivo and to enhance LTP [67]. Curcumin, shown to act as an HSF1 activator, increases BDNF levels in the hippocampus and reduces memory loss in rodent models of Alzheimer's disease (AD) $[68,69]$. Another study showed that activation of HSF1 and/or CREB during synaptic formation induces Hsp70 expression in postsynaptic structures [70-72]. Since 
the formation of long-term memory requires rapid synthesis of several new proteins, the participation of $\mathrm{Hsp} / \mathrm{Hsc70}$ as molecular chaperones in this process is absolutely necessary.

HSF1 also mediates the expression of $\beta$-amyloid precursor protein (APP) [73], and HSEs are found in the promoter of the APP gene. Various types of stress (HS, ethanol, treatment with sodium arsenite) lead to the activation of APP transcription. The APP protein is known to be involved in the transmission of intercellular signals and in cell adhesion, promoting contacts between neurons and the formation of new synapses [73,74].

Currently, it is known that the action of stress factors that leads to protein denaturation is not the sole pathway leading to HSF1 activation. For instance, it has been shown in C. elegans that serotonin, which is involved in the stress response in all animals and modulates their physiological and metabolic adaptation to adverse conditions [75,76], promotes the activation of HSF1 independent of temperature elevation [75-77]. Serotonin is sufficient for the short-term induction of Hsp70 and thermal tolerance. Serotonin is known to play an important role in learning and memory, and a decrease in its level in the mammalian brain leads to memory impairment $[78,79]$.

Interestingly, Hsp70 and Hsp60 levels have been elevated in daphnia placed in water previously exposed to predators (fish) [80]. It has also been shown that Hsp70 is synthesized in the brain of a fish (Carassius auratus) under the influence of cortisol released at the sight of a predator. This phenomenon may be associated with the memorization of threats and the formation of a defensive response and/or avoidance reaction [81]. Similarly, repeated presentation of a food odor or a visual danger stimulus triggers Hsp70 expression in the nervous system of the crab Chasmagnathus granulatus [82]. In rats, the stress caused by immersion in water has been shown to cause a significant increase in the mRNA levels of Hsp70 and Hsc70 in the hippocampus [83,84]. Thus, in addition to proteotoxic forms of stress, psychophysiological stress such as a danger can cause the induction of Hsp70 family protein expression.

A role of HSP70 in memory has also been demonstrated in rodent models $[56,85]$. The increase in the level of Hsp70 proteins in mice and rats was detected using different training protocols. Both Hsp70 and Hsc70 are induced in the hippocampus after stress-related spatial learning (contextual fear conditioning, CFC, a behavioral paradigm based on the ability to learn and remember aversive stimuli) [60-62]. The concentration of Hsp70 increases in the cerebellum after a two-way avoidance task, with the maximal level expression observed during the task solution phase and a decrease after the memory consolidation phase $[60,86]$. However, the time of maximum Hsp70 induction after training varies depending on the study protocol. In Reference [62], a short-term increase in Hsp70 levels in the hippocampus was observed $1 \mathrm{~h}$ after training. The authors suggest that the rapid induction of Hsp70 in the hippocampus is due to the activation of PKA and CREB during and immediately after training [87]. Injection of recombinant Hsp70 ( $\mathrm{rHsp70}$ ) at a concentration of $0.5 \mathrm{mg} / \mathrm{mL}$ into the dorsal hippocampus immediately after exercise promoted learning and memory. At the same time, administration of rHsp70 at a concentration of $0.25 \mathrm{or} 1 \mathrm{mg} / \mathrm{mL} \operatorname{did}$ not affect memory consolidation. It is possible that Hsp70 at high concentrations is toxic or activates pro-inflammatory signals [88,89]. In line with this possibility, transgenic mice that constitutively express high levels of Hsp70 have previously been shown to exhibit reduced learning ability in some tests [90]. The authors suggest that a constant high level of Hsp70 causes stable changes in the structure of synapses and increase in LTP, with no further increase in LTP detected after training.

A moderate increase in temperature leading to Hsp70 induction has been shown to increase learning ability. For example, fluctuations in water temperature leading to Hsps production have a positive effect on memory formation in the pond snail Lymnaea stagnalis [91]. Similarly, mild HS restores memory in the D. melanogaster Volabo and Agnostic mutants that normally have learning and memory problems [92,93].

The relationship between stress and memory is illustrated by "Yerkes-Dodson law" [94], which postulates that, up to a certain limit, stress promotes memory, but with a further increase in the intensity of stress, the ability to remember decreases. This phenomenon may 
be explained by the fact that, under excessive stress, the synthesis of Hsp70 is suppressed due to the rapid activation of the stress kinases p38 and JNK, which inhibit the activity of HSF1 $[95,96]$.

In addition to participating in protein folding, Hsp70 can modulate the activity of many signaling proteins that are involved in various regulatory cascades. Thus, Hsp70 is known to inhibit the activation of the p38/JNK stress kinases under mild stress or normal conditions $[97,98]$. It has also been shown that the injection of rHsp70 after CFC leads to a change in the activity of the MAPK signaling pathway, enhancing the ERK1/2 cascade while reducing the activity of p38/JNK. Furthermore, administration of rHsp70 increases the level of CREB phosphorylation in the hippocampus. Presumably, ERK1/2 activity is necessary for the phosphorylation of CREB and CRE-dependent transcription of genes critical for memory $[85,99]$. Additionally, ERK1/2 phosphorylate synapsin I protein, leading to the mediator release and strengthening of the existing synapses, as well as the formation of new synapses [100].

Many experiments using different mouse strains with several $h s p 70$ family genes deleted have demonstrated their sensitivity to ischemia and shown a higher probability of neurodegenerative diseases in these mice [101-104]. However, to our knowledge, there have not been reports describing the effect of Hsp70 knockout on memory formation. These studies would significantly improve our understanding of the molecular mechanisms underlying Hsp70 involvement in memory formation and consolidation. In particular, we used the conditioned courtship suppression paradigm (CCSP) to elucidate the roles of $h s p 70$ genes in memory formation in a D. melanogaster model [105]. We found that a constitutively low level of Hsp70 is required for learning and short- and long-term memory formation in males. Strains with all six $h s p 70$ genes deleted demonstrated poor ability to learn and establish short-term memory (STM) and complete inability to form long-term memory (LTM) in the CCSP (Figure 3). The presence of at least one hsp70 copy was sufficient to restore the ability to form STM and partially rescued LTM under normal conditions. A transcriptome analysis revealed that males with different $h s p 70$ copy numbers after courtship suppression differ significantly in the expression of several groups of genes involved in the memory process, reproduction, and immunity. Importantly, our analysis revealed a few pathways involved in memory formation and consolidation, including the cAMP signaling cascade, which depends on the presence of $h s p 70$ in the genome [105]. 

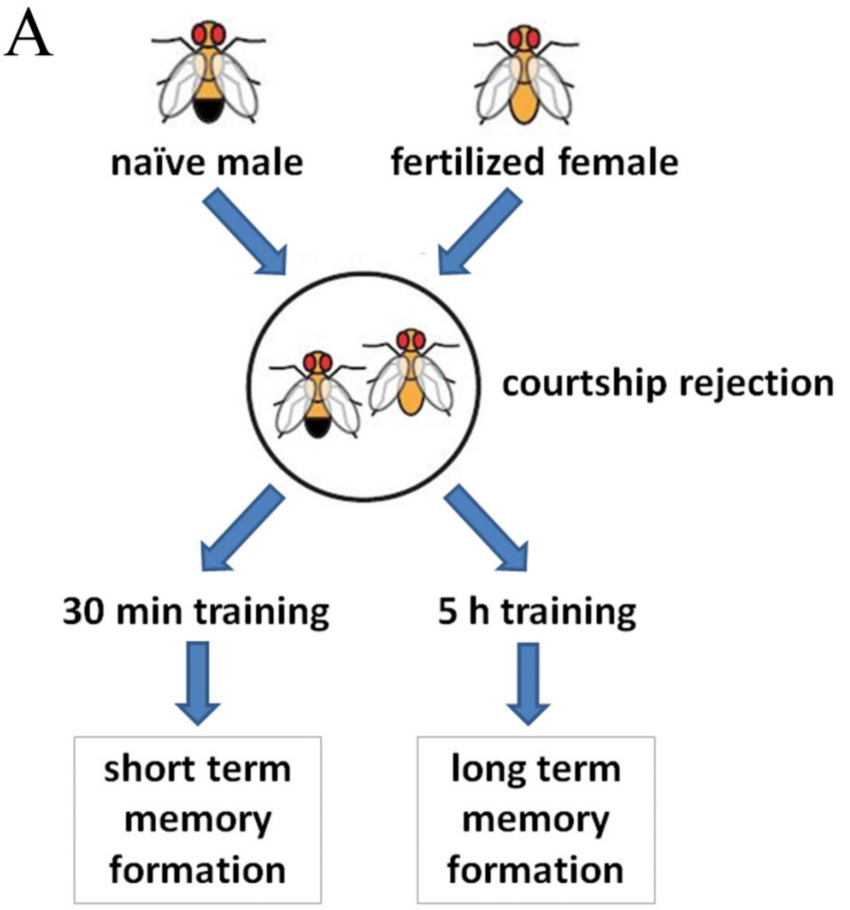

\section{B}
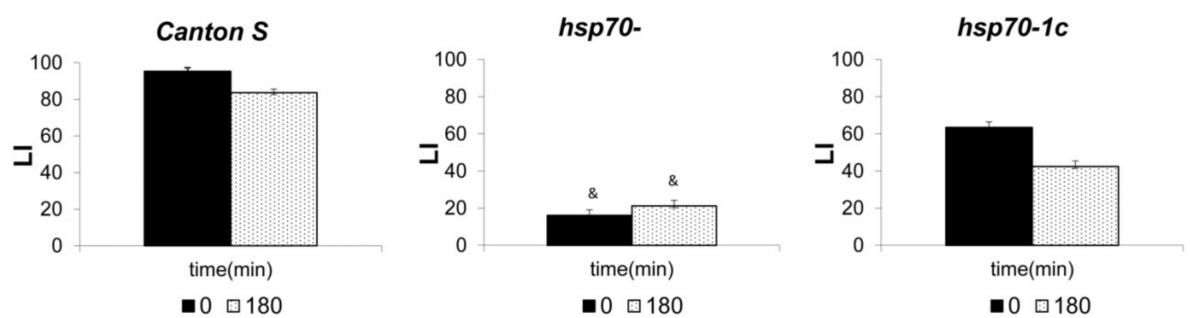

LONG-TERM MEMORY

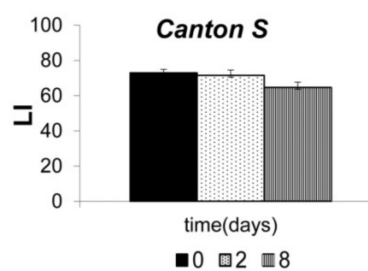

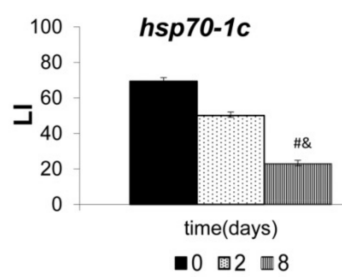

Figure 3. Results of an experiment on the effect of Hsp70 on memory. (A) A fertilized Drosophila female rejects the male's advances by spraying him with an anti-aphrodisiac secretion. The male, who remembers the reaction of the fertilized female, later refuses to court fertilized females. (B) STM and LTM in males of the Canton S strain with six copies of the Hsp70 gene, the Hsp70-knockout strain (Hsp70-), and the strain with one restored copy of the Hsp70 gene (Hsp70-1c). The absence of Hsp70 led to a decrease in STM and loss of LTM, whereas restoring a single copy of Hsp70 restored STM and LTM, compared to the corresponding memory levels in the Hsp70-negative strain. LI refers to learning index. \&, \#- $p<0.05$. [105].

Generally, from the data currently available, it can be concluded that HSF1 and CREB form a joint regulatory network that determines the interaction of the stress response system and memory formation (Figure 4). Their joint participation in this interaction is necessary for the induction of proteins involved in the reorganization of existing synapses and the formation of new ones (i.e., PSD95, synapsin I, synaptophysin, SAP97, BDNF, and APP). In addition, Hsp70 family proteins are required for newly synthesized synaptic protein 
folding, reorganization of the synaptic actin cytoskeleton, and modulation of signaling cascades involved in memory formation.

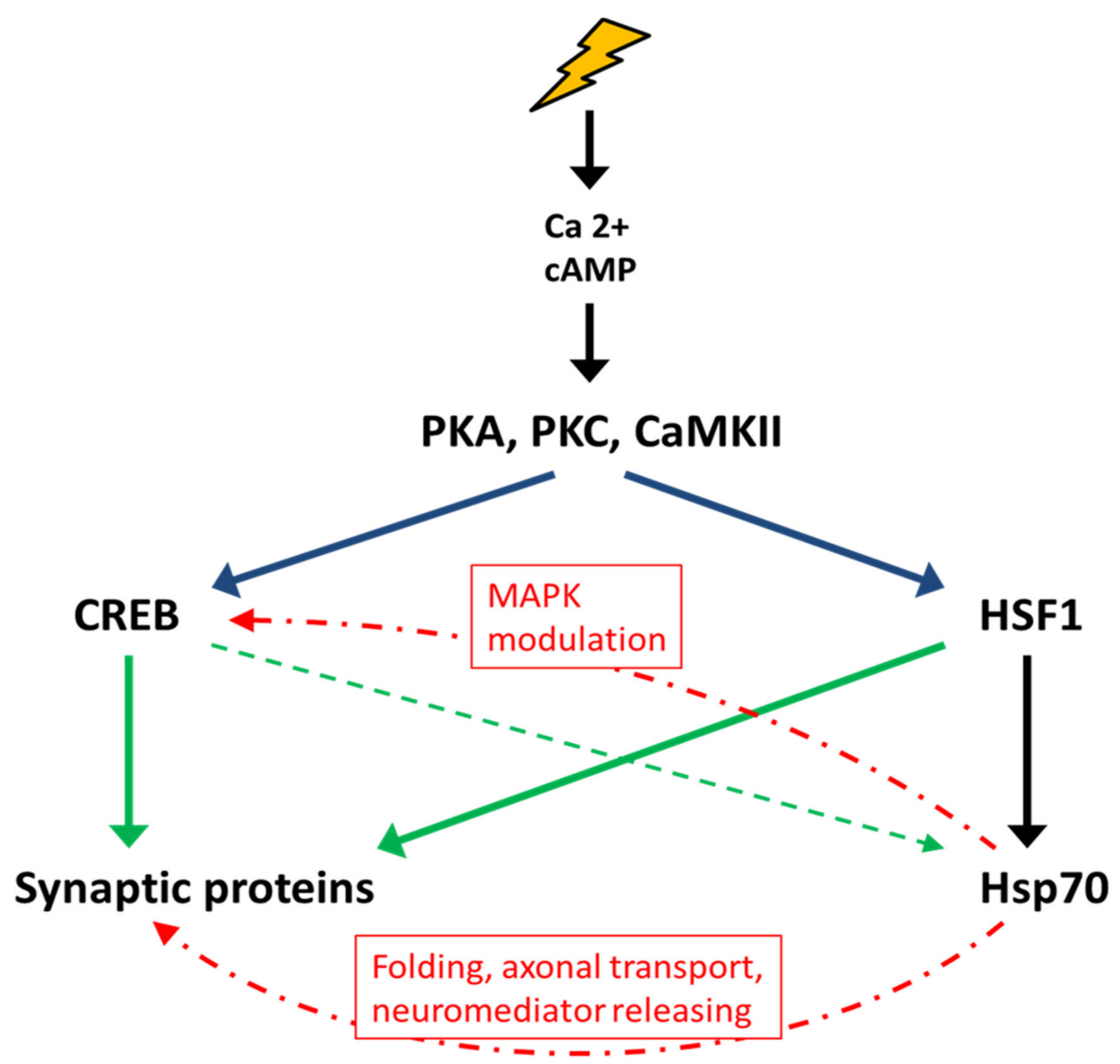

Figure 4. Interactions between the stress response and memory formation. Stress stimuli lead to an increase in the concentration of calcium and cAMP in the cytosol in CNS cells and the activation of protein kinases PKA, PKC, CaMKII, etc., which are involved in the regulation of the activity of transcription factors, in particular, CREB and HSF1. Both CREB and HSF1 initiate the transcription of genes encoding synaptic proteins and Hsp70. In turn, Hsp70 promotes the folding and transport of synaptic proteins and the release of neurotransmitters, activates the MAPK signaling cascade, and ensures the structural integrity of synapses by interacting with the cytoskeleton.

\section{Hsp70 is Involved in the Functioning of Synapses and Protects the Synaptic Network from Stress-Induced Damage}

Hsp70/Hsc70 proteins are continuously synthesized in the nervous system under normal physiological conditions at all stages of ontogenesis (in the absence of stress) [106-108]. Thus, Hsc70 expression is found in preimplantation mouse embryos at the 2 blastocyst stage [109]. During subsequent development, high levels of Hsc70 are maintained in the cytosol and nuclei of neuroectoderm cells during neural plate differentiation, neural tube closure and organogenesis [110].

Several studies $[106,111]$ have shown that the Hsc70 level is elevated in all neuronal tissues (retina, cerebellum, cortex, and brainstem) compared to that in other organs. Hsc70 levels reach 2 to $3 \%$ of the total protein content in rat spinal cord cells [112]. The constitutive synthesis of Hsp70 in the brains of mouse embryos begins much later than Hsc70 synthesis, 
on the 15th day of development. Importantly, in mice, Hsc70 is localized in neurons, while Hsp70 is mainly localized in glia. At the same time, glia may secrete various types of Hsps, mainly Hsp70, that are then internalized by neurons, mainly in the synaptic region. This process is activated under stress conditions, particularly by moderate temperature elevation $[101,106,113-115]$. In the postnatal period, the CNS has a high constitutive level of Hsp70 expression compared to other organs and tissues [116]. The expression of Hsp70 in the CNS correlates with a high constitutive level of HSFs [117].

A high level of Hsc70 expression has been observed in all synaptic fractions (synaptic membranes, synaptic junctions (SJs), and postsynaptic density (PSD) elements), not only in newly formed synapses but also in previously existing synapses [118]. Hsc70 is a component of synaptic vesicles and is necessary for the recirculation of synaptic vesicles in presynaptic nerve endings $[119,120]$. On the other hand, constitutive synthesis of Hsp70 has been observed in the SJ and PSD fractions of the forebrain. Most of the newly synthesized synaptic proteins are transported from the neuron body along the entire length of the axon. During this long-term transport along the axon, some of the neuron bodies lose their native structure. As a result of slow axonal transport, misfolded and functionally inactive proteins that enter synapses accumulate in the synaptic region. The preservation of the native structure and function of synaptic proteins is fundamentally important for the functioning of neurons [121]. Thus, high levels of Hsc70 and Hsp70 in synapses are necessary to restore and/or maintain the native conformation of the transported proteins [118]. Hsp70 also interacts with the cytoskeleton, stabilizing the structural morphology of synapses and thereby preserving synaptic transmission [122].

The expression of Hsp70 in different areas of the central nervous system increases under stress [123]. A slight rise in temperature, which induces Hsps expression, protects nerve cells from the effects of an even higher temperature, which can be lethal in nerve cells that have not been preheated. This phenomenon is called induced thermotolerance and is particularly important for poikilothermic animals [124,125]. Experiments using either nerve cell cultures transfected with Hsp70-expressing constructs or transgenic animals overexpressing Hsp70 in the CNS have shown that Hsp70 plays an important neuroprotective role [126-128]. Under stress conditions, synaptic activity must be maintained to prevent disruption of vital connections in the nervous system. Obviously, selective overexpression of Hsp70 in the synaptic region increases the level of synaptic protection. It has been shown that Hsp70, induced by stress, is localized to the synapses of the rat brain [118]. Another independent study has found that hyperthermia causes the translocation of Hsc70 to the synaptic region [129]. The authors suggest that $\mathrm{Hsp} / \mathrm{Hsc70}$ protects the nervous system at the functional level by supporting neurotransmission in synapses during stress. It has also been shown that chronic hypoxia induces the synthesis of Hsp70, which is necessary to maintain the expression level of presynaptic proteins. A direct interaction has been found between Hsp70 and the presynaptic protein syntaxin. Thus, heat shock-induced Hsp70 expression supports the release of neurotransmitters at elevated temperatures or during ischemia, providing synaptic homeostasis [130,131].

\section{Hsp70 Is an Effective Neuroprotector for Brain Ischemia}

Overexpression of inducible Hsp70 protects the brain against ischemia. This effect has been shown in both cell cultures and animal models of stroke [132]. The expression of transgenic Hsp70 protects primary neurons from heat shock and plays a crucial role in determining the fate of neurons after ischemia [133]. Ischemia, which leads to hypoxic nerve tissue damage, induces the induction of Hsp70 synthesis [16,134]. Ischemic stroke affects two areas: the ischemic nucleus, in which nerve cells undergo apoptosis and/or necrosis, and the "penumbra", in which the survival of neurons is possible. In cerebral ischemia in rats, neurons expressing Hsp70 have been shown to be preferentially located in the penumbra region at the border of the viable tissue surrounding the infarct nucleus, and in the infarct region, Hsp70 has also been shown to be induced in microglia, astrocytes, and endothelial cells $[16,134,135]$. In transgenic mice overexpressing Hsp70, the effects of 
cerebral ischemia are significantly less pronounced than those in wild-type mice $[136,137]$. On the other hand, knocking out Hsp70 genes leads to a significant increase in the volume of affected nerve tissue in experimental focal ischemia in mice [101,102]. Geranylgeranylacetone, an inducer of Hsps synthesis, also exhibits a neuroprotective effect in animal models of ischemia and traumatic brain injury [138,139].

Endogenous Hsp70 contributes to the increased survival of neurons in ischemia due to its ability to block apoptosis and because of its anti-inflammatory properties. Hsp70 can inhibit apoptosis at both early and later stages. Thus, Hsp70 has been shown to inhibit the activation of SAPK/JNK family stress kinases, which represent the main triggers of apoptosis through the phosphorylation of $\mathrm{p} 53$ and the antiapoptotic protein bcl-2 [97,98]. Hsp70 also inhibits the formation of apoptosomes, involving cytochrome $c$, Apaf- 1 , and procaspase 9. Moreover, Hsp70 blocks apoptosis-inducing factor (AIF) translation to the nucleus $[16,102,104,140]$. In the case of ischemia, the trafficking of the pro-apoptotic receptor Fas and the secretion of FasL bound with Fas increase. Hsp70 inhibits Fasmediated apoptosis by interfering with the transport of the Fas receptor from the Golgi complex to the cell surface [16]. Additionally, endogenous Hsp70 prevents the activation of the pro-inflammatory factor NF- $\mathrm{kB}$ and its transport to the nucleus. This effect is mediated by the interaction of Hsp70 with IkB (inhibitor of kB). As a result, overexpression of Hsp70 leads to a decrease in the production of major pro-inflammatory mediators such as NO and ROS [16,141].

The neuroprotective potential of not only endogenous Hsp70 expressed in nerve tissue cells but also exogenous (recombinant) $\mathrm{Hsp} 70$ in ischemia was demonstrated. When administered intranasally in mice, full-size recombinant Hsp70 effectively penetrates the brain and exhibits a pronounced anti-inflammatory effect $[103,142,143]$. Similarly, it has been shown that intranasal administration of Hsp70 for 5 days reduces one-half the volume of the ischemic lesion in a photothrombotic stroke mouse model [144]. This procedure reduces the apoptosis of neurons in the penumbra and significantly increases the expression of synaptophysin, which indicates the restoration of synaptic networks. In addition, exogenous Hsp70 promotes increased neurogenesis in the hippocampus after ischemic stroke [144].

A promising approach for the treatment of ischemic conditions is the creation of chimeric constructs that combine the Hsp70 gene with a protein transduction domain, such as Tat from HIV-1, which facilitates the transport of fusion protein to the central nervous system by crossing the blood-brain barrier after intravenous or intraperitoneal administration. These proteins have shown higher neuroprotective activity in mice with induced ischemia than unmodified Hsp70 [145-147]. At the same time, exogenous chimeric Hsp70 has been shown to stimulate neuroblast differentiation and proliferation, as well as CREB phosphorylation in the hippocampus, and to improve memory [85].

Thus, both endogenous and exogenous Hsp70 effectively protect nerve tissue, including the main "substrate" of memory, i.e., synaptic structures, from damage during ischemia. This protection allows us to recommend further research on the possibility of using both recombinant Hsp70 and inducers of endogenous Hsp70 synthesis as efficient and harmless neuroprotectors in the treatment of ischemic strokes.

\section{Hsp70 Prevents Neurodegeneration and Promotes Memory Recovery in Alzheimer's Disease Models}

The described neuroprotective properties of Hsp70 may be of great importance for the prevention and treatment of various neurodegenerative diseases, such as Alzheimer's disease $(\mathrm{AD})$, the frequency of which has recently increased dramatically in developed countries as a result of increased life span [148,149]. The cause of neurodegeneration in many cases is proteinopathies, i.e., protein folding disorders, leading to excessive accumulation and aggregation of certain proteins in the central nervous system. These neuropathologies include Parkinson's disease and dementia with Lewy bodies (DLB), which develop due to aggregation of $\alpha$-synuclein; frontotemporal dementia (tauopathy); Huntington's disease belonging to a group of polyglutamine disorders; and amyloidosis 
(Alzheimer's disease and Creutzfeldt-Jakob disease) [150-153]. Among the listed diseases, $\mathrm{AD}$ is currently of the greatest socioeconomic importance. The course of sporadic and hereditary forms of AD includes prolonged deterioration of the patients' mental condition, often lasting years. Typical symptoms are progressive memory loss and the development of dementia, and the outcome of $\mathrm{AD}$ is inevitably the death of patients [148,149]. More than 100 million cases of Alzheimer's disease are predicted to be diagnosed 2050 [154]. It is assumed that the main cause for the development of $\mathrm{AD}$ is the accumulation in the brain of soluble and highly toxic oligomers and insoluble aggregates of the so-called A $\beta$ peptide, which is a product of the proteolysis of the APP protein, an important participant in intercellular communication in the nervous system [155]. Alternative hypotheses have been proposed on the basis that the key factor in the development of AD is considered to be the aggregation of hyperphosphorylated tau protein (tauopathy), chronic inflammation of brain tissues (neuroinflammation), or the accumulation of mutations in mitochondrial DNA, leading to dysfunction of the mitochondrial respiratory chain and the development of oxidative stress [156-158]. Currently, the main models of AD are represented by various transgenic strains of rodent species that express mutant forms of APP and $\beta / \gamma$ secretases (proteolytic enzymes involved in the proteolysis of APP via the amyloidogenic pathway to form $A \beta$ peptides) [159-161]. In these animal models, at the age of 5 to 6 months, $A \beta$ deposition and neurodegeneration are detected in the cortex and hippocampus, with subsequent loss of cognitive function. A model of bulbectomized mice that develop all major manifestations of $\mathrm{AD}$ a few months after the surgical removal of the olfactory bulbs has also been considered valid $[142,162,163]$. The main clinical feature used in studies of mouse models of $\mathrm{AD}$ is spatial memory loss, usually tested through the Morris water maze, and an increase in $\beta$-amyloid levels in specific areas of the brain [164].

Several groups have shown that the chaperone properties of Hsp70 are of great promise to cure neurodegenerative diseases, including AD. The decrease in Hsp70 levels in CNS tissues observed with age may be one of the factors contributing to the accumulation of toxic $A \beta$ oligomers and tau aggregates, increasing the risk of AD [165]. Most authors postulate the importance of a decrease in the levels of Hsp70 and Hsc70 in the development of AD [166]. Thus, according to Franklin et al. 2005, tau aggregation is largely associated with a decrease in the chaperone activity of Hsp70 and other Hsps in aged individuals. On the other hand, some authors show an increase in Hsp70 levels at the early stages of AD, with Hsp70 co-localizing with tau protein aggregates [165]. Hsp70 and Hsc70 are involved in the degradation of hyperphosphorylated tau by ubiquitinylation of the latter with the participation of the ubiquitin ligase CHIP, which increases the survival of neurons in tauopathy $[165,167,168]$. The phosphorylated residues on tau act as recognition sites for Hsp70, marking the protein for ubiquitinylation and subsequent proteasomal degradation by the E3 ligase CHIP [169].

There is also evidence that Hsp70 interferes with the oligomerization of purified A $\beta$ in vitro [170]. However, Hsp70 does not reduce the toxicity of pre-oligomerized A $\beta$; that is it is not able to dissolve oligomers [171]. On the other hand, the introduction of an Hsp70-producing adenovirus vector into a primary culture of $A \beta$-expressing neurons dramatically increases the survival rate of the culture (fivefold) and reduces the level of $\mathrm{A} \beta$ accumulation in the cytoplasm [172].

Transgenic mice expressing a mutant APP producing A $\beta$ peptides with a high tendency to aggregate, after crossing with transgenic mice overexpressing Hsp70 show a decrease in $A \beta$ levels, a decrease in neurodegeneration (reduced loss of neurons and synapses), and recovery in terms of cognitive function (memory ability as measured by Morris test) compared to cross with wild-type mice [173]. This outcome is not due to a decrease in the production of $A \beta$ but results from the activation of its phagocytosis and degradation systems via IDE (insulin-degrading enzyme, an $A \beta$-degrading enzyme involved in the degradation of $A \beta$ ) [173]. Induction of Hsp70 synthesis by geranylgeranylacetone in mice expressing mutant APP leads to a decrease in $A \beta$ levels and memory recovery in the 
Morris test [174]. In addition to the IDE, the MAPK pathway activation also participates in the effect of Hsp70 to reduce Aß40/42 production in APP- transgenic mice [175].

The induction of Hsp70 with the subsequent development of a neuroprotective effect is mediated by the trimerization of HSF1 under the influence of stress factors or specific chemical compounds. HSF1 may also have an alternative neuroprotective effect, independent of trimerization, Hsp accumulation, and activation of signaling pathways, including the CaMKII, PKA, casein kinase II, and PI-3K-Akt pathways. Overexpression of HSF1 completely blocked mutant huntingtin-mediated toxicity in rat cerebellar granule neuronal (CGN) cultures. The authors suggest that this effect is mediated by the class III histone deacetylase (HDAC) SIRT1, which is known to have strong neuroprotective effects, through a direct interaction between monomeric HSF1 and SIRT1 in the nuclei of neurons [176].

Models of bulbectomized mice that develop all major manifestations of $\mathrm{AD}$ a few months after surgical removal of the olfactory bulbs are also considered to be valid [142,162,163]. Surgical removal of the olfactory bulbs (bulbectomy) in mice causes the development of several symptoms characteristic of $\mathrm{AD}$, including increased levels of $\mathrm{A} \beta$, neurodegeneration in the temporal cortex and hippocampus; deficient serotonin, acetylcholine, and glutamatergic system levels; and memory loss $[162,163]$. In addition, changes in the A $\beta$ level and other manifestations of $\mathrm{AD}$ follow a certain pattern after bulbectomy. The concentration of $\mathrm{A} \beta$ in the brain increases significantly 1.5-2 months after bulbectomy (5- to 6-fold compared to sham-operated mice) but then gradually decreases, reaching a minimum 6 months after surgery. Then, the concentration of $A \beta$ begins to increase further (7- to 8-fold compared to the sham-operated animals 12 months after the operation). Changes in the level of $A \beta$ correlate with the ability of experimental animals to learn and remember in the Morris water test [177]. In bulbectomized animals, spatial memory is significantly reduced 1.5 months after surgery compared to sham-operated mice but is subsequently restored (6 months after bulbectomy, corresponding to a minimal concentration of $A \beta$ ). In addition, a strong negative correlation between the concentration of $\mathrm{A} \beta$ (and the degree of memory loss) and the level of endogenous Hsp70 in the brains of bulbectomized mice has been observed. In this study, the Hsp70 level begins to increase shortly after the removal of the olfactory bulb, reaches a maximum 6 months after surgery, and then declines. By the twelfth month, it becomes significantly lower than the level of Hsp70 in sham-operated mice. Furthermore, the maximum level of Hsp70 corresponds to the period of maximal memory recovery and a decrease in the $A \beta$ concentration. These findings suggest that increased Hsp70 synthesis in the brain after bulbectomy is a compensatory mechanism that is activated in response to brain injury and to some extent contributes to the temporary recovery of cognitive functions. The mechanism of the observed protective action of endogenous Hsp70 may be realized by the endogenous Hsp70 facilitation of blocking tau and $A \beta$ aggregation and promoting their degradation $[165,172,174,178]$.

Hsp70 may have important implications and clinical prospects not only in the case of $\mathrm{AD}$ but also in other proteinopathies leading to neurodegeneration. The neuroprotective effect of Hsp70 overexpression has been shown in many models of Parkinson's disease in vitro and in vivo. Heat shock-mediated or geldanamycin-induced induction of Hsp70 can prevent $\alpha$-synuclein-induced cell death in yeast, Drosophila and mouse models of PD [179-181]. Thus, it has been shown that Hsp70 prevents the formation of toxic $\alpha$-synuclein oligomers that subsequently aggregate into insoluble fibril-forming Levi bodies, which is considered the main cause of Parkinson's disease [182,183]. In addition, Hsp70 in combination with Hsp40 and Hsp110 participates in the dissolution of $\alpha$-synuclein amyloid fibrils to form $\alpha$-synuclein monomers in vitro [17-19]. Finally, Hsp70 stimulates autophagocytosis of $\alpha$-synuclein fibrils and, facilitated by Hsp40 and E3 ubiquitin ligase CHIP, degradation of alpha-synuclein monomers via ubiquitin-proteasomal pathway [20]. Additionally, Hsp70-mediated disaggregation and autophagy are necessary for the quality control of polyglutamine proteins, including huntingtin, whose aggregation is the cause of Huntington's disease [184]. Induction of Hsps by geldanamycin derivatives in vitro inhibits aggregation of the prion protein PrPSc; thus, prion infection develops faster in Hsp70-/- 
knockdown mice than in wild-type mice after PrPSc inoculation [185]. In summary, the effects of intracellular Hsp70 on the prevention of protein aggregate formation in the development of neuropathies, tau, alpha-synuclein, and polyglutamine proteins are realized through three main pathways: folding/degradation of monomers and prevention of the formation of oligomers and dissolution of aggregates and autophagy. Currently, chemical inducers of Hsp70 synthesis, such as geldanamycin derivatives, radicicol, or geranylgeranylacetone, are considered possible therapeutic drugs for various neurodegenerative diseases [186].

Exogenous Hsp70, as well as endogenous Hsp70, has a strong neuroprotective effect, as demonstrated in several AD models. The addition of exogenous Hsp70 induces microglial activation and promotes A $\beta$ phagocytosis in vitro [187]. Transgenic mice and Drosophila flies secreting Hsp70 into intercellular medium have been constructed. In strains obtained by crossing extracellular Hsp70 producers with those carrying APP transgenes expressing $A \beta$ and prone to the development of neurodegenerative processes, a pronounced neuroprotective effect has been observed compared to the control cross or wild-type strain [188]. Several investigations $[103,142,143,189]$ have shown that recombinant Hsp70 labeled with Alexa Fluor or radioactive iodine penetrates the brain when administered intranasally and accumulates mainly in the cortex and hippocampus, the structures most severely affected in AD. Sub-chronic intranasal administration of recombinant human Hsp70 has resulted in a decrease in $A \beta$ concentration, activation of neurogenesis, and restoration of cognitive function (particularly spatial memory) in two mouse models of $\mathrm{AD}$, i.e., bulbectomized mice and 5XFAD transgenic mice [142,189]. Furthermore, analysis of the hippocampal transcriptome of 5XFAD transgenic mice intranasally treated with recombinant Hsp70 shows a significant decrease in the expression of genes critical for the development of neuroinflammation, which plays an important role in the development of $\mathrm{AD}[158,189]$. In addition, the expression of genes critical for antigen presentation, in particular, belonging to MHC classes I and II, has been shown to be significantly increased [143]. Transcriptome studies have also shown an increase in the main neurorepair markers and increased activity of neurotransmitter synthesis systems after administration of exogenous Hsp70 (Figure 5). In addition, intranasal administration of Hsp70 has resulted in the activation of genes involved in the regulation of the MAPK cascade [143], which plays an important role in cell proliferation, synaptic plasticity, and memory consolidation [94]. These data are in good agreement with the work presented in Reference [85], which shows the modulating effect of exogenous Hsp70 on the activity of the MAPK cascade. Finally, administration of recombinant Hsp70 leads to reduced A $\beta$ levels in the brain and restored neuron density in bulbectomized and transgenic mice [142,189]. Chronic intranasal administration of Hsp70 to ageing mice results in a slight increase in longevity, as well as an increase in neuron density and synaptophysin levels in the cortex and hippocampus, which indicates the restoration of the synaptic network that degrades with age [190]. Bulbectomized transgenic 5XFAD and ageing mice treated with recombinant Hsp70 have been shown to have greater memory recovery, as revealed in the Morris water maze test (Figure 5) [142,189]. 


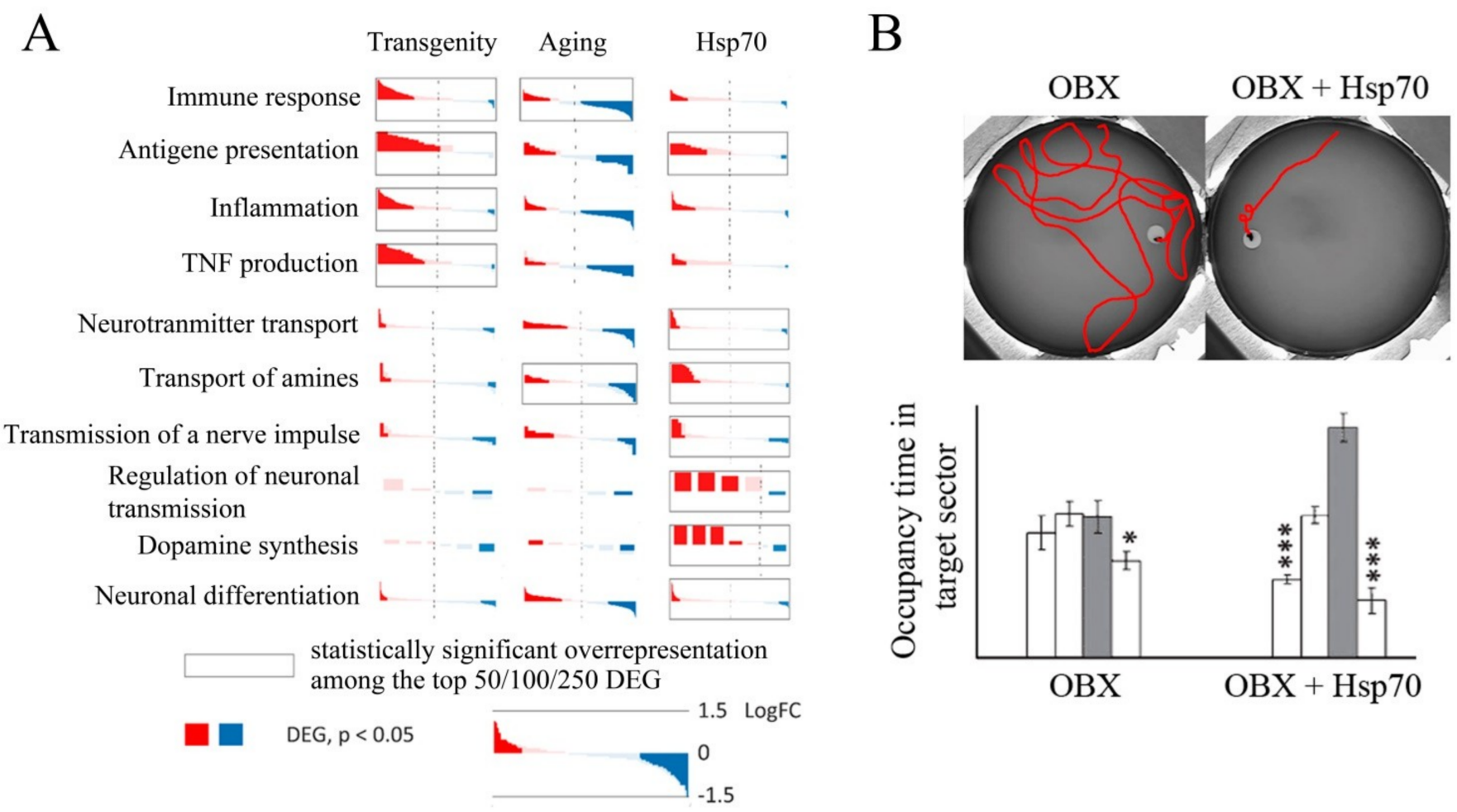

Figure 5. (A) Differentially expressed genes (DEGs) in transgenic 5XFAD mice, ageing mice, and transgenic mice after administration of exogenous Hsp70. (B) Restoration of spatial memory in bulbectomized (OBX) mice as indicated by performance in the Morris maze when exogenous Hsp70 is administered. ${ }^{*}-p<0.05 ; * *-p<0.001$.

There are several cases when human recombinant Hsp70 or Hsp70 inductors were successfully used in clinics [191,192]. For example, the treatment with Hsp70 was applied to patients with lysosomal storage disease (LSD) which often leads to severe damage of CNS [191]; however, application of Hsp70 in clinics is beyond the scope of this review.

Generally speaking, Hsp70 may play a dual role in memory formation and various types of neurodegeneration described above. First of all, Hsp70 may participate in different memory-related processes exploring its well-known chaperone properties. On the other hand, inducible Hsp70 sometimes found outside the cells at trace concentration, as well as exogenous recombinant Hsp70, may exercise its "chaperokin" properties and serve as a "danger signal" activating innate immunity and other protective cellular systems.

\section{Conclusions}

Hsp70 family members are involved in the formation and maintenance of memory in different ways. First, the stimuli that trigger the stress response and the induction of Hsp70 synthesis also activate the processes of memory and the formation of new synapses. The transcription factor HSF1 promotes not only Hsps production but also the rapid synthesis of synaptic proteins. Furthermore, Hsp70 functions as a molecular chaperone, facilitating the transport and folding of synaptic proteins and modulating the signaling cascades involved in the formation of synapses. Furthermore, Hsp70 (both endogenous and exogenous) protects neurons and synaptic structures from damage under stress (heat shock, hypoxia, etc.). Finally, Hsp70 interferes with the oligomerization and aggregation of proteins prone to amyloid formation, preventing neurodegeneration. Taken together, the accumulated data allow us to consider Hsp70 synthesis inducers and recombinant Hsp70 per se as promising neuroprotectors.

Author Contributions: Conceptualization, O.G.Z., M.B.E. and D.G.G.; methodology, O.G.Z. and D.G.G.; software, D.G.G.; validation, O.G.Z., M.B.E. and D.G.G.; formal analysis, D.G.G.; investigation, O.G.Z., M.B.E. and D.G.G.; resources, O.G.Z.; data curation, M.B.E.; writing-original draft 
preparation, O.G.Z., M.B.E. and D.G.G.; writing-review and editing, O.G.Z., M.B.E. and D.G.G.; visualization, D.G.G.; supervision, M.B.E.; project administration, D.G.G.; funding acquisition, M.B.E. and D.G.G. All authors have read and agreed to the published version of the manuscript.

Funding: This research was funded by Russian Science Foundation grant numbers 19-14- 00167 (D.G.G.) and 17-74-30030 (M.B.E.).

Acknowledgments: We are grateful to Artem Davletshin and Alexander Rezvykh for technical assistance.

Conflicts of Interest: The authors declare no conflict of interest.

$\begin{array}{ll}\text { Abbreviations } \\ \text { AD } & \text { Alzheimer's disease: } \\ \text { APP } & \text { amyloid precursor protein; } \\ \text { CaMKII } & \text { Ca }{ }^{2+} \text { / calmodulin-dependent protein kinase II; } \\ \text { cAMP } & \text { cyclic adenosine monophosphate; } \\ \text { CRE } & \text { cAMP response elements; } \\ \text { CNS } & \text { central nervous system; } \\ \text { CREB } & \text { CRE-binding protein; } \\ \text { ERK } & \text { extracellular signal-regulated kinases; } \\ \text { HS } & \text { heat shock; } \\ \text { HSE } & \text { heat shock element; } \\ \text { HSF } & \text { heat shock factor; } \\ \text { Hsps } & \text { heat shock proteins; } \\ \text { JNK } & \text { c-Jun N-terminal kinases; } \\ \text { LTM } & \text { long-term memory; } \\ \text { LTP } & \text { long-term potentiation; } \\ \text { MAPK } & \text { mitogen-activated protein kinase; } \\ \text { PKA } & \text { cAMP-dependent protein kinase; } \\ \text { PKC } & \text { protein kinase C; } \\ \text { STM } & \text { short-term memory; } \\ \text { STP } & \text { short-term potentiation } \\ & \end{array}$

\section{References}

1. Robertson, R.; Kuhnert, C.; Dawson, J. Thermal avoidance during flight in the locust Locusta migratoria. J. Exp. Biol. 1996, 199, 1383-1393. [CrossRef] [PubMed]

2. Rosenzweig, M.R.; Bennett, E.L. Psychobiology of plasticity: Effects of training and experience on brain and behavior. Behav. Brain Res. 1996, 78, 57-65. [CrossRef]

3. Sandry, J.; Trafimow, D.; Marks, M.J.; Rice, S. Adaptive Memory: Evaluating Alternative Forms of Fitness-Relevant Processing in the Survival Processing Paradigm. PLoS ONE 2013, 8, e60868. [CrossRef]

4. Forest, J.; Sunada, H.; Dodd, S.; Lukowiak, K. Training Lymnaea in the presence of a predator scent results in a long-lasting ability to form enhanced long-term memory. J. Comp. Physiol. A 2016, 202, 399-409. [CrossRef]

5. Hawkins, R.D.; Byrne, J.H. Associative Learning in Invertebrates. Cold Spring Harb. Perspect. Biol. 2015, 7, a021709. [CrossRef]

6. Lukowiak, K.; Orr, M.; De Caigny, P.; Lukowiak, K.S.; Rosenegger, D.; Han, J.I.; Dalesman, S. Ecologically relevant stressors modify long-term memory formation in a model system. Behav. Brain Res. 2010, 214, 18-24. [CrossRef]

7. Zhao, H.; Bucci, D.; Weltzin, M.; Drew, K. Effects of aversive stimuli on learning and memory in Arctic ground squirrels. Behav. Brain Res. 2004, 151, 219-224. [CrossRef]

8. Ooi, F.K.; Prahlad, V. Olfactory experience primes the heat shock transcription factor HSF-1 to enhance the expression of molecular chaperones inC. elegans. Sci. Signal. 2017, 10, eaan4893. [CrossRef]

9. Cohen, A.O.; Matese, N.G.; Filimontseva, A.; Shen, X.; Shi, T.; Livne, E.; Hartley, C.A. Aversive learning strengthens episodic memory in both adolescents and adults. Learn. Mem. 2019, 26, 272-279. [CrossRef]

10. Sitaraman, D.; Zars, M.; LaFerriere, H.; Chen, Y.-C.; Sable-Smith, A.; Kitamoto, T.; Rottinghaus, G.E.; Zars, T. Serotonin is necessary for place memory in Drosophila. Proc. Natl. Acad. Sci. USA 2008, 105, 5579-5584. [CrossRef]

11. Hartl, F.U.; Bracher, A.; Hayer-Hartl, M. Molecular chaperones in protein folding and proteostasis. Nat. Cell Biol. 2011, 475, 324-332. [CrossRef]

12. Morimoto, R. Cells in stress: Transcriptional activation of heat shock genes. Science 1993, 259, 1409-1410. [CrossRef]

13. Lindquist, S.; Craig, E.A. The Heat-Shock Proteins. Annu. Rev. Genet. 1988, 22, 631-677. [CrossRef]

14. Yura, T.; Nagai, H.; Mori, H. Regulation of the Heat-Shock Response in Bacteria. Annu. Rev. Microbiol. 1993, 47, 321-350. [CrossRef] 
15. Rubin, D.M.; Mehta, A.D.; Zhu, J.; Shoham, S.; Chen, X.; Wells, Q.R.; Palter, K.B. Genomic structure and sequence analysis of Drosophila melanogaster HSC70 genes. Gene 1993, 128, 155-163. [CrossRef]

16. Kim, J.Y.; Han, Y.; Lee, J.E.; Yenari, M.A. The 70-kDa heat shock protein (Hsp70) as a therapeutic target for stroke. Expert Opin. Ther. Targets 2018, 22, 191-199. [CrossRef]

17. Finka, A.; Sharma, S.K.; Goloubinoff, P. Multi-layered molecular mechanisms of polypeptide holding, unfolding and disaggregation by HSP70/HSP110 chaperones. Front. Mol. Biosci. 2015, 2, 29. [CrossRef]

18. Gao, X.; Carroni, M.; Nussbaum-Krammer, C.; Mogk, A.; Nillegoda, N.B.; Szlachcic, A.; Guilbride, D.L.; Saibil, H.R.; Mayer, M.P.; Bukau, B. Human Hsp70 Disaggregase Reverses Parkinson's-Linked $\alpha$-Synuclein Amyloid Fibrils. Mol. Cell 2015, 59, 781-793. [CrossRef]

19. Wentink, A.S.; Nillegoda, N.B.; Feufel, J.; Ubartaitè, G.; Schneider, C.P.; Rios, P.D.L.; Hennig, J.; Barducci, A.; Bukau, B. Molecular dissection of amyloid disaggregation by human HSP70. Nat. Cell Biol. 2020, 587, 483-488. [CrossRef]

20. Witt, S.N. Hsp70 molecular chaperones and Parkinson's disease. Biopolymers 2010, 93, 218-228. [CrossRef]

21. Aneja, R.; Odoms, K.; Dunsmore, K.; Shanley, T.P.; Wong, H. Extracellular Heat Shock Protein-70 Induces Endotoxin Tolerance in THP-1 Cells. J. Immunol. 2006, 177, 7184-7192. [CrossRef]

22. Kustanova, G.A.; Murashev, A.N.; Karpov, V.L.; Margulis, B.A.; Guzhova, I.V.; Prokhorenko, I.R.; Grachev, S.V.; Evgen'Ev, M.B Exogenous heat shock protein 70 mediates sepsis manifestations and decreases the mortality rate in rats. Cell Stress Chaperones 2006, 11, 276-286. [CrossRef]

23. Rozhkova, E.; Yurinskaya, M.; Zatsepina, O.; Garbuz, D.; Karpov, V.; Surkov, S.; Murashev, A.; Ostrov, V.; Margulis, B.; Evgen'Ev, M.; et al. Exogenous mammalian extracellular HSP70 reduces endotoxin manifestations at the cellular and organism levels. Ann. N. Y. Acad. Sci. 2010, 1197, 94-107. [CrossRef]

24. Vinokurov, M.; Ostrov, V.; Yurinskaya, M.; Garbuz, D.; Murashev, A.; Antonova, O.; Evgen’Ev, M. Recombinant human Hsp70 protects against lipoteichoic acid-induced inflammation manifestations at the cellular and organismal levels. Cell Stress Chaperones 2011, 17, 89-101. [CrossRef] [PubMed]

25. Borges, T.J.; Lopes, R.L.; Pinho, N.G.; Machado, F.D.; Souza, A.P.D.; Bonorino, C. Extracellular Hsp70 inhibits proinflammatory cytokine production by IL-10 driven down-regulation of C/EBP $\beta$ and C/EBP. Int. J. Hyperth. 2013, 29, 455-463. [CrossRef] [PubMed]

26. Hsu, J.-H.; Yang, R.-C.; Lin, S.-J.; Liou, S.-F.; Dai, Z.-K.; Yeh, J.-L.; Wu, J.-R. Exogenous Heat Shock Cognate Protein 70 Pretreatment Attenuates Cardiac and Hepatic Dysfunction with Associated Anti-inflammatory Responses in Experimental Septic Shock. Shock 2014, 42, 540-547. [CrossRef]

27. Ghosh, A.K.; Sinha, D.; Mukherjee, S.; Biswas, R.; Biswas, T. LPS stimulates and Hsp70 down-regulates TLR4 to orchestrate differential cytokine response of culture-differentiated innate memory CD8+ T cells. Cytokine 2015, 73, 44-52. [CrossRef]

28. Asea, A. Stress proteins and initiation of immune response: Chaperokine activity of hsp72. Exerc. Immunol. Rev. 2005, 11, 34-45. [PubMed]

29. Morimoto, R.I.; Kline, M.P.; Bimston, D.N.; Cotto, J.J. The heat-shock response: Regulation and function of heat-shock proteins and molecular chaperones. Essays Biochem. 1997, 32, 17-29. [PubMed]

30. Akerfelt, M.; Morimoto, R.I.; Sistonen, L. Heat shock factors: Integrators of cell stress, development and lifespan. Nat. Rev. Mol. Cell Biol. 2010, 11, 545-555. [CrossRef]

31. Garbuz, D.G. Regulation of heat shock gene expression in response to stress. Mol. Biol. 2017, 51, 352-367. [CrossRef]

32. Morimoto, R.I.; Santoro, M. Stress-Inducible responses and heat shock proteins: New pharmacologic targets for cytoprotection. Nat. Biotechnol. 1998, 16, 833-838. [CrossRef]

33. Voellmy, R. On mechanisms that control heat shock transcription factor activity in metazoan cells. Cell Stress Chaperones 2004, 9 , 122-133. [CrossRef]

34. Morange, M. HSFs in Development. Mol. Chaperones Health Dis. 2006, 172, 153-169. [CrossRef]

35. Roh, J.S.; Sohn, D.H. Damage-Associated Molecular Patterns in Inflammatory Diseases. Immune Netw. 2018, 18, e27. [CrossRef]

36. Bausinger, H.; Lipsker, D.; Ziylan, U.; Manié, S.; Briand, J.; Cazenave, J.; Muller, S.; Haeuw, J.; Ravanat, C.; De La Salle, H.; et al. Endotoxin-free heat-shock protein 70 fails to induce APC activation. Eur. J. Immunol. 2002, 32, 3708-3713. [CrossRef]

37. Kandel, E.R. The molecular biology of memory: cAMP, PKA, CRE, CREB-1, CREB-2, and CPEB. Mol. Brain 2012, 5, 14. [CrossRef]

38. Mayford, M.; Siegelbaum, S.A.; Kandel, E.R. Synapses and Memory Storage. Cold Spring Harb. Perspect. Biol. 2012, 4 , a005751. [CrossRef]

39. Flexner, J.B.; Flexner, L.B.; Stellar, E. Memory in Mice as Affected by Intracerebral Puromycin. Science 1963, 141, 57-59. [CrossRef]

40. Kandel, E.R. The Molecular Biology of Memory Storage: A Dialogue Between Genes and Synapses. Science 2001, 294, 1030-1038. [CrossRef]

41. Giese, K.P.; Mizuno, K. The roles of protein kinases in learning and memory. Learn. Mem. 2013, 20, 540-552. [CrossRef] [PubMed]

42. Bliss, T.V.P.; Collingridge, G.L. A synaptic model of memory: Long-term potentiation in the hippocampus. Nat. Cell Biol. 1993, 361, 31-39. [CrossRef]

43. Lynch, M.A. Long-Term Potentiation and Memory. Physiol. Rev. 2004, 84, 87-136. [CrossRef] [PubMed]

44. Morimoto, R.I. Regulation of the heat shock transcriptional response: Cross talk between a family of heat shock factors, molecular chaperones, and negative regulators. Genes Dev. 1998, 12, 3788-3796. [CrossRef] [PubMed] 
45. Visvader, J.; Sassone-Corsi, P.; Verma, I.M. Two adjacent promoter elements mediate nerve growth factor activation of the c-fos gene and bind distinct nuclear complexes. Proc. Natl. Acad. Sci. USA 1988, 85, 9474-9478. [CrossRef] [PubMed]

46. Thekkuveettil, A.; Lakhotia, S.C. Regulation of HSP70 in excitatory neurons: Possible implications for neuronal functioning. J. Biosci. 1996, 21, 631-639. [CrossRef]

47. Robertson, M. Interpersonal Therapy: An Introduction for Clinicians. Australas. Psychiatry 1999, 7, 25-27. [CrossRef]

48. Alberini, C.M. Transcription Factors in Long-Term Memory and Synaptic Plasticity. Physiol. Rev. 2009, 89, 121-145. [CrossRef]

49. Choi, H.S.; Li, B.; Lin, Z.; Huang, E.; Liu, A.Y. cAMP and cAMP-dependent protein kinase regulate the human heat shock protein 70 gene promoter activity. J. Biol. Chem. 1991, 266, 11858-11865. [CrossRef]

50. Han, S.I.; Oh, S.Y.; Woo, S.H.; Kim, K.H.; Kim, J.H.; Kim, H.D.; Kang, H.S. Implication of a small GTPase Rac1 in the activation of c-Jun N-terminal kinase and heat shock factor in response to heat shock. J. Biol. Chem. 2001, 276, 1889-1895. [CrossRef]

51. Bijur, G.N.; Jope, R.S. Opposing actions of phosphatidylinositol 3-kinase and glycogen synthase kinase-3beta in the regulation of HSF-1 activity. J. Neurochem. 2000, 75, 2401-2408. [CrossRef]

52. Murshid, A.; Chou, S.D.; Prince, T.; Zhang, Y.; Bharti, A.; Calderwood, S.K. Protein kinase A binds and activates heat shock factor 1. PLoS ONE 2010, 5, e13830. [CrossRef]

53. Gungor, B.; Gombos, I.; Crul, T.; Ayaydin, F.; Szabó, L.; Török, Z.; Mátés, L.; Vígh, L.; Horváth, I. Rac1 Participates in Thermally Induced Alterations of the Cytoskeleton, Cell Morphology and Lipid Rafts, and Regulates the Expression of Heat Shock Proteins in B16F10 Melanoma Cells. PLoS ONE 2014, 9, e89136. [CrossRef]

54. Török, Z.; Crul, T.; Maresca, B.; Schütz, G.J.; Viana, F.; Dindia, L.; Piotto, S.; Brameshuber, M.; Balogh, G.; Péter, M.; et al. Plasma membranes as heat stress sensors: From lipid-controlled molecular switches to therapeutic applications. Biochim. Biophys. Acta Biomembr. 2014, 1838, 1594-1618. [CrossRef] [PubMed]

55. Price, B.D.; Calderwood, S.K. Ca ${ }^{2+}$ is essential for multistep activation of the heat shock factor in permeabilized cells. Mol. Cell. Biol. 1991, 11, 3365-3368. [CrossRef]

56. Porto, R.R.; Alvares, L.D.O. Role of HSP70 in Plasticity and Memory. In Heat Shock Proteins in Human Diseases; Springer Science and Business Media LLC: Berlin/Heidelberg, Germany, 2019; pp. 53-67.

57. Donovan, M.R.; Marr, M.T. dFOXO Activates Large and Small Heat Shock Protein Genes in Response to Oxidative Stress to Maintain Proteostasis in Drosophila. J. Biol. Chem. 2016, 291, 19042-19050. [CrossRef]

58. Kaletsky, R.; Lakhina, V.; Arey, R.N.; Williams, A.; Landis, J.N.; Ashraf, J.; Murphy, C.T. The C. elegans adult neuronal IIS/FOXO transcriptome reveals adult phenotype regulators. Nat. Cell Biol. 2016, 529, 92-96. [CrossRef] [PubMed]

59. Kim, S.Y.; Webb, A.E. Neuronal functions of FOXO/DAF-16. Nutr. Health Aging 2017, 4, 113-126. [CrossRef] [PubMed]

60. Pizarro, J.M.; Haro, L.S.; Barea-Rodriguez, E.J. Learning associated increase in heat shock cognate 70 mRNA and protein expression. Neurobiol. Learn. Mem. 2003, 79, 142-151. [CrossRef]

61. Igaz, L.M.; Bekinschtein, P.; Izquierdo, I.; Medina, J.H. One-trial aversive learning induces late changes in hippocampal CaMKIIalpha, Homer 1a, Syntaxin 1a and ERK2 protein levels. Mol. Brain Res. 2004, 132, 1-12. [CrossRef]

62. Porto, R.R.; Dutra, F.D.; Crestani, A.P.; Holsinger, R.D.; Quillfeldt, J.A.; De Bittencourt, P.I.H.; Alvares, L.D.O. HSP70 Facilitates Memory Consolidation of Fear Conditioning through MAPK Pathway in the Hippocampus. Neuroscience 2018, 375, $108-118$. [CrossRef] [PubMed]

63. King, M.K.; Pardo, M.; Cheng, Y.; Downey, K.; Jope, R.S.; Beurel, E. Glycogen synthase kinase-3 inhibitors: Rescuers of cognitive impairments. Pharmacol. Ther. 2014, 141, 1-12. [CrossRef] [PubMed]

64. Jiang, Y.-Q.; Wang, X.-L.; Cao, X.-H.; Ye, Z.; Li, L.; Cai, W.-Q. Increased heat shock transcription factor 1 in the cerebellum reverses the deficiency of Purkinje cells in Alzheimer's disease. Brain Res. 2013, 1519, 105-111. [CrossRef] [PubMed]

65. Kondo, N.; Katsuno, M.; Adachi, H.; Minamiyama, M.; Doi, H.; Matsumoto, S.; Miyazaki, Y.; Iida, M.; Tohnai, G.; Nakatsuji, H.; et al. Heat shock factor-1 influences pathological lesion distribution of polyglutamine-induced neurodegeneration. Nat. Commun. 2013, 4, 1405. [CrossRef] [PubMed]

66. Lu, Y.; Christian, K.; Lu, B. BDNF: A key regulator for protein synthesis-dependent LTP and long-term memory? Neurobiol. Learn. Mem. 2008, 89, 312-323. [CrossRef]

67. Chen, Y.; Wang, B.; Liu, D.; Li, J.J.; Xue, Y.; Sakata, K.; Zhu, L.Q.; Heldt, S.A.; Xu, H.; Liao, F.F. Hsp90 chaperone inhibitor 17-AAG attenuates A $\beta$-induced synaptic toxicity and memory impairment. J. Neurosci. 2014, 34, 2464-2470. [CrossRef] [PubMed]

68. Teiten, M.-H.; Reuter, S.; Schmucker, S.; Dicato, M.; Diederich, M. Induction of heat shock response by curcumin in human leukemia cells. Cancer Lett. 2009, 279, 145-154. [CrossRef]

69. Zhang, L.; Fang, Y.; Xu, Y.; Lian, Y.; Xie, N.; Wu, T.; Zhang, H.; Sun, L.; Zhang, R.; Wang, Z. Curcumin Improves Amyloid $\beta$-Peptide (1-42) Induced Spatial Memory Deficits through BDNF-ERK Signaling Pathway. PLoS ONE 2015, 10, e0131525. [CrossRef]

70. Rao, A.; Steward, O. Evidence that protein constituents of postsynaptic membrane specializations are locally synthesized: Analysis of proteins synthesized within synaptosomes. J. Neurosci. 1991, 11, 2881-2895. [CrossRef]

71. Hooper, P.L.; Durham, H.D.; Török, Z.; Hooper, P.L.; Crul, T.; Vígh, L. The central role of heat shock factor 1 in synaptic fidelity and memory consolidation. Cell Stress Chaperones 2016, 21, 745-753. [CrossRef]

72. Suzuki, T.; Usuda, N.; Murata, S.; Nakazawa, A.; Ohtsuka, K.; Takagi, H. Presence of molecular chaperones, heat shock cognate (Hsc) 70 and heat shock proteins (Hsp) 40, in the postsynaptic structures of rat brain. Brain Res. 1999, 816, 99-110. [CrossRef]

73. Dewji, N.N.; Do, C. Heat shock factor-1 mediates the transcriptional activation of Alzheimer's beta-amyloid precursor protein gene in response to stress. Mol. Brain Res. 1996, 35, 325-328. [CrossRef] 
74. Dewji, N.N.; Do, C.; Bayney, R.M. Transcriptional activation of Alzheimer's beta-amyloid precursor protein gene by stress. Mol. Brain Res. 1995, 33, 245-253. [CrossRef]

75. Chaouloff, F.; Berton, O.; Mormède, P. Serotonin and stress. Neuropsychopharmacology 1999, 21, 28S-32S. [CrossRef]

76. Joëls, M.; Baram, T.Z. The neuro-symphony of stress. Nat. Rev. Neurosci. 2009, 10, 459-466. [CrossRef] [PubMed]

77. Tatum, M.C.; Ooi, F.K.; Chikka, M.R.; Chauve, L.; Martinez-Velazquez, L.A.; Steinbusch, H.W.; Morimoto, R.I.; Prahlad, V. Neuronal Serotonin Release Triggers the Heat Shock Response in C. elegans in the Absence of Temperature Increase. Curr. Biol. 2015, 25, 163-174. [CrossRef]

78. Enver, T.; Soneji, S.; Joshi, C.; Brown, J.; Iborra, F.; Orntoft, T.; Thykjaer, T.; Maltby, E.; Smith, K.; Abu Dawud, R.; et al. Cellular differentiation hierarchies in normal and culture-adapted human embryonic stem cells. Hum. Mol. Genet. 2005, 14, 3129-3140. [CrossRef] [PubMed]

79. Schmitt, J.; Wingen, M.; Ramaekers, J.; Evers, E.; Riedel, W. Serotonin and Human Cognitive Performance. Curr. Pharm. Des. 2006, 12, 2473-2486. [CrossRef]

80. Pijanowska, J.; Kloc, M. Daphnia response to predation threat involves heat-shock proteins and the actin and tubulin cytoskeleton. Genesis 2004, 38, 81-86. [CrossRef]

81. Kagawa, N.; Mugiya, Y. Brain HSP70 mRNA Expression is Linked with Plasma Cortisol Levels in Goldfish (Carassius auratus) Exposed to a Potential Predator. Zool. Sci. 2002, 19, 735-740. [CrossRef]

82. Frenkel, L.; Dimant, B.; Suarez, L.; Portiansky, E.; Delorenzi, A. Food odor, visual danger stimulus, and retrieval of an aversive memory trigger heat shock protein HSP70 expression in the olfactory lobe of the crab Chasmagnathus granulatus. Neuroscience 2012, 201, 239-251. [CrossRef] [PubMed]

83. Fukudo, S.; Abe, K.; Hongo, M.; Utsumi, A.; Itoyama, Y. Brain-gut induction of heat shock protein (HSP) 70 mRNA by psychophysiological stress in rats. Brain Res. 1997, 757, 146-148. [CrossRef]

84. Fukudo, S.; Abe, K.; Itoyama, Y.; Mochizuki, S.; Sawai, T.; Hongo, M. Psychophysiological stress induces heat shock cognate protein 70 messenger RNA in the hippocampus of rats. Neuroscience 1999, 91, 1205-1208. [CrossRef]

85. Kwon, H.J.; Kim, W.; Jung, H.Y.; Kang, M.S.; Kim, J.W.; Hahn, K.R.; Yoo, D.Y.; Yoon, Y.S.; Hwang, I.K.; Kim, D.W. Heat shock protein 70 increases cell proliferation, neuroblast differentiation, and the phosphorylation of CREB in the hippocampus. Lab. Anim. Res. 2019, 35, 21. [CrossRef]

86. Ambrosini, M.V.; Mariucci, G.; Tantucci, M.; Van Hooijdonk, L.; Ammassari-Teule, M. Hippocampal 72-kDa heat shock protein expression varies according to mice learning performance independently from chronic exposure to stress. Hippocampus 2005, 15, 413-417. [CrossRef] [PubMed]

87. Izquierdo, I.; Bevilaqua, L.R.; Rossato, J.I.; Bonini, J.S.; Medina, J.H.; Cammarota, M. Different molecular cascades in different sites of the brain control memory consolidation. Trends Neurosci. 2006, 29, 496-505. [CrossRef] [PubMed]

88. Calderwood, S.K. Heat shock proteins in extracellular signaling. Methods 2007, 43, 167. [CrossRef]

89. De Maio, A. Extracellular heat shock proteins, cellular export vesicles, and the Stress Observation System: A form of communication during injury, infection, and cell damage. It is never known how far a controversial finding will go! Dedicated to Ferruccio Ritossa. Cell Stress Chaperones 2011, 16, 235-249. [CrossRef]

90. Ammon-Treiber, S.; Grecksch, G.; Angelidis, C.; Vezyraki, P.; Höllt, V.; Becker, A. Emotional and learning behaviour in mice overexpressing heat shock protein 70. Neurobiol. Learn. Mem. 2008, 90, 358-364. [CrossRef] [PubMed]

91. Foster, N.L.; Lukowiak, K.; Henry, T.B. Time-related expression profiles for heat shock protein gene transcripts (HSP40, HSP70) in the central nervous system of Lymnaea stagnalis exposed to thermal stress. Commun. Integr. Biol. 2015, 8, e1040954. [CrossRef]

92. Grotewiel, M.S.; Beck, C.D.O.; Wu, K.H.; Zhu, X.-R.; Davis, R.L. Integrin-mediated short-term memory in Drosophila. Nat. Cell Biol. 1998, 391, 455-460. [CrossRef]

93. Nikitina, E.A.; Kaminskaya, A.N.; Molotkov, D.A.; Popov, A.V.; Savvateeva-Popova, E.V. Effect of heat shock on courtship behavior, sound production, and learning in comparison with the brain content of LIMK1 in Drosophila melanogaster males with altered structure of the LIMK1 gene. J. Evol. Biochem. Physiol. 2014, 50, 154-166. [CrossRef]

94. Teigen, K.H. Yerkes-Dodson: A Law for all Seasons. Theory Psychol. 1994, 4, 525-547. [CrossRef]

95. Chu, B.; Soncin, F.; Price, B.D.; Stevenson, M.A.; Calderwood, S.K. Sequential Phosphorylation by Mitogen-activated Protein Kinase and Glycogen Synthase Kinase 3 Represses Transcriptional Activation by Heat Shock Factor-1. J. Biol. Chem. 1996, 271, 30847-30857. [CrossRef] [PubMed]

96. Anckar, J.; Sistonen, L. Heat Shock Factor 1 as a Coordinator of Stress and Developmental Pathways. Chem. Biol. Pteridines Folates 2007, 594, 78-88. [CrossRef]

97. Gabai, V.L.; Meriin, A.B.; Yaglom, J.A.; Volloch, V.Z.; Sherman, M.Y. Role of Hsp70 in regulation of stress-kinase JNK: Implications in apoptosis and aging. FEBS Lett. 1998, 438, 1-4. [CrossRef]

98. Kumar, Y.; Tatu, U.; Budigi, Y. Stress protein flux during recovery from simulated ischemia: Induced heat shock protein 70 confers cytoprotection by suppressing JNK activation and inhibiting apoptotic cell death. Proteomics 2003, 3, 513-526. [CrossRef]

99. Thomas, G.M.; Huganir, R.L. MAPK cascade signalling and synaptic plasticity. Nat. Rev. Neurosci. 2004, 5, 173-183. [CrossRef]

100. Giachello, C.N.G.; Fiumara, F.; Giacomini, C.; Corradi, A.; Milanese, C.; Ghirardi, M.; Benfenati, F.; Montarolo, P.G. MAPK/Erkdependent phosphorylation of synapsin mediates formation of functional synapses and short-term homosynaptic plasticity. J. Cell Sci. 2010, 123, 881-893. [CrossRef] 
101. Lee, S.-H.; Kim, M.; Yoon, B.-W.; Kim, Y.-J.; Ma, S.-J.; Roh, J.-K.; Lee, J.-S.; Seo, J.-S. Targeted hsp70.1 Disruption Increases Infarction Volume After Focal Cerebral Ischemia in Mice. Stroke 2001, 32, 2905-2912. [CrossRef]

102. Lee, S.-H.; Kwon, H.-M.; Kim, Y.-J.; Lee, K.-M.; Kim, M.; Yoon, B.-W. Effects of Hsp70.1 Gene Knockout on the Mitochondrial Apoptotic Pathway After Focal Cerebral Ischemia. Stroke 2004, 35, 2195-2199. [CrossRef]

103. Yurinskaya, M.; Zatsepina, O.; Vinokurov, M.; Bobkova, N.; Garbuz, D.; Morozov, A.; Kulikova, D.; Mitkevich, V.; Makarov, A.; Funikov, S.; et al. The Fate of Exogenous Human HSP70 Introduced into Animal Cells by Different Means. Curr. Drug Deliv. 2015, 12, 524-532. [CrossRef]

104. Choudhury, S.; Bae, S.; Ke, Q.; Lee, J.Y.; Kim, J.; Kang, P.M. Mitochondria to nucleus translocation of AIF in mice lacking Hsp70 during ischemia/reperfusion. Basic Res. Cardiol. 2011, 106, 397-407. [CrossRef] [PubMed]

105. Zatsepina, O.G.; Nikitina, E.A.; Shilova, V.Y.; Chuvakova, L.N.; Sorokina, S.; Vorontsova, J.E.; Tokmacheva, E.V.; Funikov, S.Y.; Rezvykh, A.P.; Evgen'Ev, M.B. Hsp70 affects memory formation and behaviorally relevant gene expression in Drosophila melanogaster. Cell Stress Chaperones 2021, 26, 575-594. [CrossRef] [PubMed]

106. Manzerra, P.; Rush, S.J.; Brown, I.R. Tissue-specific differences in heat shock protein hsc70 and hsp70 in the control and hyperthermic rabbit. J. Cell Physiol. 1997, 170, 130-137. [CrossRef]

107. Foster, J.; Brown, I. Basal expression of stress-inducible hsp70 mRNA detected in hippocampal and cortical neurons of normal rabbit brain. Brain Res. 1996, 724, 73-83. [CrossRef]

108. Bodega, G.; Hernández, C.; Suárez, I.; Martín, M.; Fernández, B. HSP70 constitutive expression in rat central nervous system from postnatal development to maturity. J. Histochem. Cytochem. 2002, 50, 1161-1168. [CrossRef]

109. Loones, M.-T.; Rallu, M.; Mezger, V.; Morange, M. HSP gene expression and HSF2 in mouse development. Cell. Mol. Life Sci. 1997, 53, 179-190. [CrossRef]

110. Loones, M.-T.; Chang, Y.; Morange, M. The distribution of heat shock proteins in the nervous system of the unstressed mouse embryo suggests a role in neuronal and non-neuronal differentiation. Cell Stress Chaperones 2000, 5, 291-305. [CrossRef]

111. D'Souza, S.M.; Brown, I.R. Constitutive expression of heat shock proteins Hsp90, Hsc70, Hsp70 and Hsp60 in neural and non-neural tissues of the rat during postnatal development. Cell Stress Chaperones 1998, 3, 188-199. [CrossRef]

112. Aquino, D.A.; Klipfel, A.A.; Brosnan, C.F.; Norton, W.T. The 70-kDa heat shock cognate protein (HSC70) is a major constituent of the central nervous system and is up-regulated only at the mRNA level in acute experimental autoimmune encephalomyelitis. J. Neurochem. 1993, 61, 1340-1348. [CrossRef] [PubMed]

113. Brown, I.R.; Rush, S.J. Expression of heat shock genes (hsp70) in the mammalian brain: Distinguishing constitutively expressed and hyperthermia-inducible mRNA species. J. Neurosci. Res. 1990, 25, 14-19. [CrossRef] [PubMed]

114. Izumoto, S.; Herbert, J. Widespread constitutive expression of HSP90 messenger RNA in rat brain. J. Neurosci. Res. 1993, 35, 20-28. [CrossRef] [PubMed]

115. Calderwood, S.K.; Mambula, S.S.; Gray, P.J.; Theriault, J.R. Extracellular heat shock proteins in cell signaling. FEBS Lett. 2007, 581, 3689-3694. [CrossRef] [PubMed]

116. Tanguay, R.M.; Wu, Y.; Khandjian, E.W. Tissue-specific expression of heat shock proteins of the mouse in the absence of stress. Dev. Genet. 1993, 14, 112-118. [CrossRef]

117. Stacchiotti, A.; Rezzani, R.; Rodella, L.; Tiberio, L.; Schiaffonati, L.; Bianchi, R. Cell-specific expression of heat shock transcription factors 1 and 2 in unstressed rat spinal cord. Neurosci. Lett. 1999, 268, 73-76. [CrossRef]

118. Bechtold, D.A.; Rush, S.J.; Brown, I.R. Localization of the Heat-Shock Protein Hsp70 to the Synapse Following Hyperthermic Stress in the Brain. J. Neurochem. 2001, 74, 641-646. [CrossRef]

119. Morgan, J.R.; Prasad, K.; Jin, S.; Augustine, G.J.; Lafer, E. Uncoating of Clathrin-Coated Vesicles in Presynaptic Terminals: Roles for Hsc70 and Auxilin. Neuron 2001, 32, 289-300. [CrossRef]

120. Leshchyns'Ka, I.; Sytnyk, V.; Richter, M.; Andreyeva, A.; Puchkov, D.; Schachner, M. The Adhesion Molecule CHL1 Regulates Uncoating of Clathrin-Coated Synaptic Vesicles. Neuron 2006, 52, 1011-1025. [CrossRef]

121. Brown, I.R. Heat Shock Proteins at the Synapse: Implications for Functional Protection of the Nervous System. In Heat Shock Proteins and the Brain: Implications for Neurodegenerative Diseases and Neuroprotection; Springer Science and Business Media LLC: Berlin/Heidelberg, Germany, 2008; pp. 239-254.

122. Klose, M.K.; Robertson, R.M. Stress-induced thermoprotection of neuromuscular transmission. Integr. Comp. Biol. 2004, 44, 14-20. [CrossRef]

123. Manzerra, P.; Brown, I.R. Expression of heat shock genes (hsp70) in the rabbit spinal cord: Localization of constitutive and hyperthermia-inducible mRNA species. J. Neurosci. Res. 1992, 31, 606-615. [CrossRef]

124. Feder, M.E.; Hofmann, G.E. Heat-Shock Proteins, Molecular Chaperones, And The Stress Response: Evolutionary and Ecological Physiology. Annu. Rev. Physiol. 1999, 61, 243-282. [CrossRef] [PubMed]

125. Evgen'Ev, M.B.; Garbuz, D.G.; Zatsepina, O.G. Heat Shock Proteins and Whole Body Adaptation to Extreme Environments; Springer Science and Business Media LLC: Berlin/Heidelberg, Germany, 2014.

126. Fink, S.L.; Chang, L.K.; Ho, D.Y.; Sapolsky, R.M. Defective Herpes Simplex Virus Vectors Expressing the Rat Brain Stress-Inducible Heat Shock Protein 72 Protect Cultured Neurons from Severe Heat Shock. J. Neurochem. 2002, 68, 961-969. [CrossRef] [PubMed]

127. Plumier, J.; Krueger, A.; Currie, R.; Kontoyiannis, D.; Kollias, G.; Pagpulatos, G. Response of transgenic mice expressing the human 70-kDa heat shock protein to cerebral ischemia. Cell Stress Chaperones 1997, 2, 162-167. [CrossRef] 
128. Yenari, M.A.; Fink, S.L.; Sun, G.H.; Chang, L.K.; Patel, M.; Kunis, D.M.; Onley, D.; Ho, D.Y.; Sapolsky, R.M.; Steinbrg, G.K. Gene therapy with HSP72 is neuroprotective in rat models of stroke and epilepsy. Ann. Neurol. 1998, 44, 584-591. [CrossRef]

129. Chen, S.; Brown, I.R. Translocation of constitutively expressed heat shock protein Hsc70 to synapse-enriched areas of the cerebral cortex after hyperthermic stress. J. Neurosci. Res. 2007, 85, 402-409. [CrossRef]

130. Fei, G.-H.; Guo, C.; Sun, H.-S.; Feng, Z.-P. HSP70 Reduces Chronic Hypoxia-Induced Neural Suppression via Regulating Expression of Syntaxin. Chem. Biol. Pteridines Folates 2008, 605, 35-40. [CrossRef]

131. Xiao, C.; Mileva-Seitz, V.; Seroude, L.; Robertson, R.M. Targeting HSP70 to motoneurons protects locomotor activity from hyperthermia inDrosophila. Dev. Neurobiol. 2007, 67, 438-455. [CrossRef]

132. Giffard, R.G.; Yenari, M.A. Many Mechanisms for Hsp70 Protection from Cerebral Ischemia. J. Neurosurg. Anesthesiol. 2004, 16, 53-61. [CrossRef]

133. Kelly, S.; McCulloch, J.; Horsburgh, K. Minimal ischaemic neuronal damage and HSP70 expression in MF1 strain mice following bilateral common carotid artery occlusion. Brain Res. 2001, 914, 185-195. [CrossRef]

134. Sharp, F.R.; Lu, A.; Tang, Y.; Millhorn, D.E. Multiple Molecular Penumbras after Focal Cerebral Ischemia. Br. J. Pharmacol. 2000, 20, 1011-1032. [CrossRef] [PubMed]

135. Gonzalez, M.F.; Shiraishi, K.; Hisanaga, K.; Sagar, S.M.; Mandabach, M.; Sharp, F.R. Heat shock proteins as markers of neural injury. Mol. Brain Res. 1989, 6, 93-100. [CrossRef]

136. Kelly, S.; Bieneman, A.; Horsburgh, K.; Hughes, D.; Sofroniew, M.V.; McCulloch, J.; Uney, J.B. Targeting Expression of hsp70i to Discrete Neuronal Populations Using the Lmo-1 Promoter: Assessment of the Neuroprotective Effects of hsp70i In vivo and In vitro. Br. J. Pharmacol. 2001, 21, 972-981. [CrossRef] [PubMed]

137. Tsuchiya, D.; Hong, S.; Matsumori, Y.; Kayama, T.; Swanson, R.; Dillman, W.H.; Liu, J.; Panter, S.S.; Weinstein, P.R. Overexpression of Rat Heat Shock Protein 70 Reduces Neuronal Injury after Transient Focal Ischemia, Transient Global Ischemia, or Kainic Acid-induced Seizures. Neurosurgery 2003, 53, 1179-1188. [CrossRef] [PubMed]

138. Yasuda, H.; Shichinohe, H.; Kuroda, S.; Ishikawa, T.; Iwasaki, Y. Neuroprotective effect of a heat shock protein inducer, geranylgeranylacetone in permanent focal cerebral ischemia. Brain Res. 2005, 1032, 176-182. [CrossRef]

139. Zhao, Z.; Faden, A.I.; Loane, D.; Lipinski, M.M.; Sabirzhanov, B.; Stoica, B. Neuroprotective Effects of Geranylgeranylacetone in Experimental Traumatic Brain Injury. Br. J. Pharmacol. 2013, 33, 1897-1908. [CrossRef]

140. Matsumori, Y.; Hong, S.M.; Aoyama, K.; Fan, Y.; Kayama, T.; Sheldon, R.A.; Vexler, Z.S.; Ferriero, D.M.; Weinstein, P.R.; Liu, J. Hsp70 Overexpression Sequesters AIF and Reduces Neonatal Hypoxic/Ischemic Brain Injury. Br. J. Pharmacol. 2005, 25, 899-910. [CrossRef]

141. Feinstein, D.L.; Galea, E.; Aquino, D.A.; Li, G.C.; Xu, H.; Reis, D.J. Heat shock protein 70 suppresses astroglial-inducible nitric-oxide synthase expression by decreasing NFkappaB activation. J. Biol. Chem. 1996, 271, 17724-17732. [CrossRef]

142. Bobkova, N.V.; Garbuz, D.G.; Nesterova, I.; Medvinskaya, N.; Samokhin, A.; Alexandrova, I.; Yashin, V.; Karpov, V.; Kukharsky, M.; Ninkina, N.N.; et al. Therapeutic Effect of Exogenous Hsp70 in Mouse Models of Alzheimer's Disease. J. Alzheimer's Dis. 2013, 38, 425-435. [CrossRef]

143. Evgen'Ev, M.; Bobkova, N.; Krasnov, G.; Garbuz, D.; Funikov, S.; Kudryavtseva, A.; Kulikov, A.; Samokhin, A.; Maltsev, A.; Nesterova, I. The Effect of Human HSP70 Administration on a Mouse Model of Alzheimer's Disease Strongly Depends on Transgenicity and Age. J. Alzheimer's Dis. 2019, 67, 1391-1404. [CrossRef]

144. Demyanenko, S.; Nikul, V.; Rodkin, S.; Davletshin, A.; Evgen'Ev, M.B.; Garbuz, D.G. Exogenous recombinant Hsp70 mediates neuroprotection after photothrombotic stroke. Cell Stress Chaperones 2021, 26, 103-114. [CrossRef]

145. Zhan, X.; Ander, B.P.; Liao, I.H.; Hansen, J.E.; Kim, C.; Clements, D.; Weisbart, R.H.; Nishimura, R.N.; Sharp, F.R. Recombinant Fv-Hsp70 Protein Mediates Neuroprotection After Focal Cerebral Ischemia in Rats. Stroke 2010, 41, 538-543. [CrossRef]

146. Doeppner, T.R.; Kaltwasser, B.; Fengyan, J.; Hermann, D.M.; Bähr, M. TAT-Hsp70 Induces Neuroprotection Against Stroke Via Anti-Inflammatory Actions Providing Appropriate Cellular Microenvironment for Transplantation of Neural Precursor Cells. Br. J. Pharmacol. 2013, 33, 1778-1788. [CrossRef]

147. Cappelletti, P.; Binda, E.; Tunesi, M.; Albani, D.; Giordano, C.; Molla, G.; Pollegioni, L. Recombinant human Tat-Hsp70-2: A tool for neuroprotection. Protein Expr. Purif. 2017, 138, 18-24. [CrossRef] [PubMed]

148. Dubois, B.; Feldman, H.; Jacova, C.; Hampel, H.; Molinuevo, J.L.; Blennow, K.; DeKosky, S.T.; Gauthier, S.; Selkoe, D.; Bateman, R.; et al. Advancing research diagnostic criteria for Alzheimer's disease: The IWG-2 criteria. Lancet Neurol. 2014, 13, 614-629. [CrossRef]

149. Kochanek, K.D.; Murphy, S.L.; Xu, J.; Arias, E. Deaths: Final Data for 2017. Natl. Vital Stat. Rep. 2019, 68, 1-77.

150. Bayer, T.A. Proteinopathies, a core concept for understanding and ultimately treating degenerative disorders? Eur. Neuropsychopharmacol. 2015, 25, 713-724. [CrossRef] [PubMed]

151. Dugger, B.N.; Dickson, D.W. Pathology of Neurodegenerative Diseases. Cold Spring Harb. Perspect. Biol. 2017, 9, a028035. [CrossRef]

152. Briston, T.; Hicks, A.R. Mitochondrial dysfunction and neurodegenerative proteinopathies: Mechanisms and prospects for therapeutic intervention. Biochem. Soc. Trans. 2018, 46, 829-842. [CrossRef] [PubMed]

153. Lanuti, P.; Ciccocioppo, F.; Bologna, G.; Ercolino, E.; Pierdomenico, L.; Simeone, P.; Pieragostino, D.; DEL Boccio, P.; Marchisio, M.; Miscia, S. Neurodegenerative diseases as proteinopathies-driven immune disorders. Neural Regen. Res. 2020, 15, 850-856. [CrossRef] 
154. Brookmeyer, R.; Johnson, E.; Ziegler-Graham, K.; Arrighi, H.M. Forecasting the global burden of Alzheimer's disease. Alzheimer's Dement. 2007, 3, 186-191. [CrossRef]

155. Müller, U.C.; Deller, T.; Korte, M. Not just amyloid: Physiological functions of the amyloid precursor protein family. Nat. Rev. Neurosci. 2017, 18, 281-298. [CrossRef] [PubMed]

156. Reisberg, B.; Saeed, M.U. Alzheimer's disease. In Comprehensive Textbook of Geriatric Psychiatry, 3rd ed.; Sadavoy, J., Jarvik, L.F., Grossberg, G.T., Meyers, B.S., Eds.; WW Norton: New York, NY, USA, 2004; pp. 449-509.

157. Swerdlow, R.H.; Burns, J.M.; Khan, S.M. The Alzheimer's Disease Mitochondrial Cascade Hypothesis. J. Alzheimer's Dis. 2010, 20, S265-S279. [CrossRef] [PubMed]

158. Heppner, F.L.; Ransohoff, R.M.; Becher, B. Immune attack: The role of inflammation in Alzheimer disease. Nat. Rev. Neurosci. 2015, 16, 358-372. [CrossRef]

159. Nazem, A.; Sankowski, R.; Bacher, M.; Al-Abed, Y. Rodent models of neuroinflammation for Alzheimer's disease. J. Neuroinflamm. 2015, 12, 74. [CrossRef] [PubMed]

160. Puzzo, D.; Gulisano, W.; Palmeri, A.; Arancio, O. Rodent models for Alzheimer's disease drug discovery. Expert Opin. Drug Discov. 2015, 10, 703-711. [CrossRef]

161. Esquerda-Canals, G.; Montoliu-Gaya, L.; Güell-Bosch, J.; Villegas, S. Mouse Models of Alzheimer's Disease. J. Alzheimer's Dis. 2017, 57, 1171-1183. [CrossRef]

162. Bobkova, N.V.; Nesterova, I.V.; Nesterov, V.V. The state of cholinergic structures in forebrain of bulbectomized mice. Bull. Exp. Biol. Med. 2001, 131, 427-431. [CrossRef]

163. Holland, D.; Brewer, J.B.; Hagler, D.J.; Fennema-Notestine, C.; Dale, A.M.; Initiative, T.A.D.N. Subregional neuroanatomical change as a biomarker for Alzheimer's disease. Proc. Natl. Acad. Sci. USA 2009, 106, 20954-20959. [CrossRef]

164. Bromley-Brits, K.; Deng, Y.; Song, W. Morris Water Maze Test for Learning and Memory Deficits in Alzheimer's Disease Model Mice. J. Vis. Exp. 2011, 53, e2920. [CrossRef]

165. Leak, R.K. Heat shock proteins in neurodegenerative disorders and aging. J. Cell Commun. Signal. 2014, 8, 293-310. [CrossRef]

166. Manavalan, A.; Mishra, M.; Feng, L.; Sze, S.K.; Akatsu, H.; Heese, K. Brain site-specific proteome changes in aging-related dementia. Exp. Mol. Med. 2013, 45, e39. [CrossRef] [PubMed]

167. Shimura, H.; Schwartz, D.; Gygi, S.P.; Kosik, K.S. CHIP-Hsc70 Complex Ubiquitinates Phosphorylated Tau and Enhances Cell Survival. J. Biol. Chem. 2004, 279, 4869-4876. [CrossRef]

168. Petrucelli, L.; Dickson, D.; Kehoe, K.; Taylor, J.; Snyder, H.; Grover, A.; De Lucia, M.; McGowan, E.; Lewis, J.; Prihar, G.; et al. CHIP and Hsp70 regulate tau ubiquitination, degradation and aggregation. Hum. Mol. Genet. 2004, 13, 703-714. [CrossRef]

169. Kumar, P.; Jha, N.K.; Jha, S.K.; Ramani, K.; Ambasta, R.K. Tau Phosphorylation, Molecular Chaperones, and Ubiquitin E3 Ligase: Clinical Relevance in Alzheimer's Disease. J. Alzheimer's Dis. 2014, 43, 341-361. [CrossRef] [PubMed]

170. Evans, C.G.; Wisén, S.; Gestwicki, J.E. Heat shock proteins 70 and 90 inhibit early stages of amyloid beta-(1-42) aggregation in vitro. J. Biol. Chem. 2006, 281, 33182-33191. [CrossRef] [PubMed]

171. Rivera, I.; Capone, R.; Cauvi, D.M.; Arispe, N.; De Maio, A. Modulation of Alzheimer's amyloid $\beta$ peptide oligomerization and toxicity by extracellular Hsp70. Cell Stress Chaperones 2018, 23, 269-279. [CrossRef] [PubMed]

172. Magrané, J.; Smith, R.C.; Walsh, K.; Querfurth, H.W. Heat shock protein 70 participates in the neuroprotective response to intracellularly expressed beta-amyloid in neurons. J. Neurosci. 2004, 24, 1700-1706. [CrossRef]

173. Hoshino, T.; Murao, N.; Namba, T.; Takehara, M.; Adachi, H.; Katsuno, M.; Sobue, G.; Matsushima, T.; Suzuki, T.; Mizushima, T. Suppression of Alzheimer's Disease-Related Phenotypes by Expression of Heat Shock Protein 70 in Mice. J. Neurosci. 2011, 31, 5225-5234. [CrossRef] [PubMed]

174. Hoshino, T.; Suzuki, K.; Matsushima, T.; Yamakawa, N.; Suzuki, T.; Mizushima, T. Suppression of Alzheimer's Disease-Related Phenotypes by Geranylgeranylacetone in Mice. PLoS ONE 2013, 8, e76306. [CrossRef]

175. Sun, Y.; Zhang, J.R.; Chen, S. Suppression of Alzheimer's disease-related phenotypes by the heat shock protein 70 inducer, geranylgeranylacetone, in APP/PS1 transgenic mice via the ERK/p38 MAPK signaling pathway. Exp. Ther. Med. 2017, 14, 5267-5274. [CrossRef]

176. Verma, P.; Pfister, J.A.; Mallick, S.; D’Mello, S.R. HSF1 protects neurons through a novel trimerization- and HSP-independent mechanism. J. Neurosci. 2014, 34, 1599-1612. [CrossRef] [PubMed]

177. Bobkova, N.; Guzhova, I.; Margulis, B.; Nesterova, I.; Medvinskaya, N.; Medvedinskaya, N.; Samokhin, A.; Alexandrova, I.; Garbuz, D.; Nudler, E.; et al. Dynamics of endogenous Hsp70 synthesis in the brain of olfactory bulbectomized mice. Cell Stress Chaperones 2013, 18, 109-118. [CrossRef] [PubMed]

178. Sulistio, Y.A.; Heese, K. The Ubiquitin-Proteasome System and Molecular Chaperone Deregulation in Alzheimer's Disease. Mol. Neurobiol. 2015, 53, 905-931. [CrossRef] [PubMed]

179. Auluck, P.K.; Bonini, N.M. Pharmacological prevention of Parkinson disease in Drosophila. Nat. Med. 2002, 8, 1185-1186. [CrossRef] [PubMed]

180. Klucken, J.; Shin, Y.; Masliah, E.; Hyman, B.T.; McLean, P.J. Hsp70 Reduces $\alpha$-Synuclein Aggregation and Toxicity. J. Biol. Chem. 2004, 279, 25497-25502. [CrossRef]

181. Flower, T.R.; Chesnokova, L.S.; Froelich, C.A.; Dixon, C.; Witt, S.N. Heat Shock Prevents Alpha-synuclein-induced Apoptosis in a Yeast Model of Parkinson's Disease. J. Mol. Biol. 2005, 351, 1081-1100. [CrossRef] [PubMed] 
182. Outeiro, T.F.; Putcha, P.; Tetzlaff, J.E.; Spoelgen, R.; Koker, M.; Carvalho, F.; Hyman, B.T.; McLean, P.J. Formation of toxic oligomeric alpha-synuclein species in living cells. PLoS ONE 2008, 3, e1867. [CrossRef]

183. Tao, J.; Berthet, A.; Citron, Y.R.; Tsiolaki, P.L.; Stanley, R.; Gestwicki, J.E.; Agard, D.A.; McConlogue, L. Hsp70 chaperone blocks $\alpha$-synuclein oligomer formation via a novel engagement mechanism. J. Biol. Chem. 2021, 296, 100613. [CrossRef]

184. Davis, A.; Pratt, W.B.; Lieberman, A.P.; Osawa, Y. Targeting Hsp70 facilitated protein quality control for treatment of polyglutamine diseases. Cell. Mol. Life Sci. 2020, 77, 977-996. [CrossRef]

185. Mays, C.E.; Armijo, E.; Morales, R.; Kramm, C.; Flores, A.; Tiwari, A.; Bian, J.; Telling, G.C.; Pandita, T.K.; Hunt, C.R.; et al. Prion disease is accelerated in mice lacking stress-induced heat shock protein 70 (HSP70). J. Biol. Chem. 2019, 294, 13619-13628. [CrossRef]

186. Ebrahimi-Fakhari, D.; Saidi, L.-J.; Wahlster, L. Molecular chaperones and protein folding as therapeutic targets in Parkinson's disease and other synucleinopathies. Acta Neuropathol. Commun. 2013, 1, 79. [CrossRef]

187. Kakimura, J.; Kitamura, Y.; Takata, K.; Umeki, M.; Suzuki, S.; Shibagaki, K.; Taniguchi, T.; Nomura, Y.; Gebicke-Haerter, P.J.; Smith, M.A.; et al. Microglial activation and amyloid-beta clearance induced by exogenous heat-shock proteins. FASEB J. 2002, 16, 601-603. [CrossRef]

188. De Mena, L.; Chhangani, D.; Fernandez-Funez, P.; Rincon-Limas, D.E. secHsp70 as a tool to approach amyloid- $\beta 42$ and other extracellular amyloids. Fly 2017, 11, 179-184. [CrossRef]

189. Evgen'Ev, M.B.; Krasnov, G.S.; Nesterova, I.V.; Garbuz, D.G.; Karpov, V.L.; Morozov, A.V.; Snezhkina, A.V.; Samokhin, A.N.; Sergeev, A.; Kulikov, A.M.; et al. Molecular Mechanisms Underlying Neuroprotective Effect of Intranasal Administration of Human Hsp70 in Mouse Model of Alzheimer's Disease. J. Alzheimer's Dis. 2017, 59, 1415-1426. [CrossRef] [PubMed]

190. Bobkova, N.V.; Evgen'Ev, M.; Garbuz, D.G.; Kulikov, A.M.; Morozov, A.; Samokhin, A.; Velmeshev, D.; Medvinskaya, N.; Nesterova, I.; Pollock, A.; et al. Exogenous Hsp70 delays senescence and improves cognitive function in aging mice. Proc. Natl. Acad. Sci. USA 2015, 112, 16006-16011. [CrossRef] [PubMed]

191. Kirkegaard, T.; Gray, J.; Priestman, D.A.; Wallom, K.-L.; Atkins, J.; Olsen, O.D.; Klein, A.; Drndarski, S.; Petersen, N.H.T.; Ingemann, L.; et al. Heat shock protein-based therapy as a potential candidate for treating the sphingolipidoses. Sci. Transl. Med. 2016, 8, 355ra118. [CrossRef]

192. Kalmar, B.; Lu, C.-H.; Greensmith, L. The role of heat shock proteins in Amyotrophic Lateral Sclerosis: The therapeutic potential of Arimoclomol. Pharmacol. Ther. 2014, 141, 40-54. [CrossRef] [PubMed] 